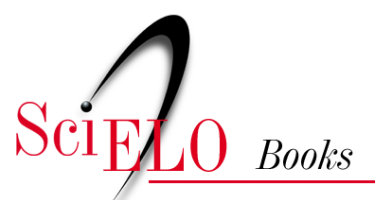

\title{
Capítulo 2. Literatura, pós-colonialidade e descolonização cultural
}

\author{
Cláudio R. V. Braga
}

\section{SciELO Books / SciELO Livros / SciELO Libros}

BRAGA, C.R.V. Literatura, pós-colonialidade e descolonização cultural. In: A literatura movente de Chimamanda Adichie: póscolonialidade, descolonização cultural e diáspora [online]. Brasília: Editora UnB, 2019, pp. 29-77. Pesquisa, inovação \& ousadia series. ISBN: 978-65-5846053-4. https://doi.org/10.7476/9786558460534.0003.

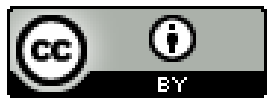

All the contents of this work, except where otherwise noted, is licensed under a Creative Commons Attribution 4.0 International license.

Todo o conteúdo deste trabalho, exceto quando houver ressalva, é publicado sob a licença Creative Commons Atribição 4.0.

Todo el contenido de esta obra, excepto donde se indique lo contrario, está bajo licencia de la licencia Creative Commons Reconocimento 4.0. 


\section{CAPÍTULO 2.}

\section{Literatura, pós-colonialidade e descolonização cultural}

\section{Um pouco de teoria}

\subsection{Pós-colonialismos}

Pós-colonial ou pós-colonialismo, teoria pós-colonial, crítica pós-colonial, pós-colonialidade e descolonização. Eis aqui expressões difundidas no mundo acadêmico, muitas vezes de maneiras conflitantes ou sobrepostas, com as quais devemos lidar neste capítulo. Em definição clássica, Ashcroft et al. (1989) esclarecem que o termo pós-colonial é usado para abarcar as culturas afetadas pelos processos de colonização europeia em todos os continentes. Tais culturas refletem profundas transformações de natureza diversificada, que perduram mesmo depois de finda a colonização (ASHCROFT, 1989, p. 2). São culturas que, na abordagem dos estudos pós-coloniais, precisam ser pensadas a partir de certas características, como: hibridismo e diferença cultural; espaço e território; mobilidade, seja ela diaspórica ou exílica; identidade e subjetividade, com destaque para o sujeito feminino; etnicidade e raça; políticas de representação; uso da língua; dominação e opressão, sejam política, econômica, social ou psicológica; e também a partir da reescritura e da reinterpretação da história. 


\section{A literatura movente de Chimamanda Adichie}

A reflexão sobre esses temas, na visão de Robert C. Young (2003), ganha força no início dos anos 1980, por meio de um conjunto de textos teóricos que surgem para alterar as formas dominantes em que as relações entre povos ocidentais e não ocidentais e seus respectivos mundos são vistas. Para Young, os ocidentais olham para o resto do mundo como se olhassem para si mesmos em um espelho, o que provoca distorções evidentes. Por isso, continua o autor, a chamada teoria pós-colonial envolve uma reorientação conceitual das perspectivas dos conhecimentos desenvolvidos fora do Ocidente, reunindo um conjunto de princípios que não estaria, de fato, organizado cientificamente, mas que serve para intervir e estimular conhecimentos alternativos nas estruturas de poder ocidentais e também não ocidentais. Por abarcar práticas e ideias tão diversas, como o feminismo e o socialismo, muitos dizem não haver uma “teoria pós-colonial” unificada, o que, de certa forma, faz sentido. Entretanto, a ausência de princípios científicos padronizados, esperados de uma teoria, não impede que o pensamento e a crítica da condição pós-colonial sejam profícuos.

Um dos principais intelectuais do pós-colonialismo, Homi Bhabha afirma que a crítica pós-colonial,

\footnotetext{
é testemunha das forças desiguais e irregulares de representação cultural envolvidas na competição pela autoridade política e social dentro da ordem do mundo moderno. As perspectivas pós-coloniais emergem do testemunho colonial dos países do Terceiro Mundo e dos discursos das “minorias” dentro das divisões geopolíticas de Leste e Oeste, Norte e Sul. (BHABHA, 1998, p. 239).
}

Portanto, os críticos pós-coloniais buscam romper com ideias eurocêntricas como as que consideram a representação cultural europeia superior às demais. É o que vemos em Frantz Fanon, Chinua Achebe, Edward Said, Ngugi wa Thiong'o, Gayatri Spivak e Homi Bhabha, dentre outros. No caso da literatura, a noção de universalidade dos textos canônicos de escritores europeus é revista, abrindo o caminho para a leitura e a análise das narrativas não europeias. 


\subsection{Dilemas das literaturas pós-coloniais}

Para Ashcroft et al. (1989), são literaturas pós-coloniais aquelas que emergiram da experiência da colonização, afirmando suas diferenças em relação aos poderes imperiais e enfatizando-as em relação às premissas estabelecidas pelo centro imperial. Tais literaturas, afirma Richard J. Lane (2013), são, de certa forma, uma reação contra o cânone literário europeu, utilizado por colonizadores, nas figuras de professores, missionários e funcionários públicos, para manter a hegemonia e a dominação europeia durante e depois da colonização (LANE, 2013, p. 487). A literatura do writing back, isto é, a que escreve como forma de resposta, ocorre de formas diversas:

Por meio da produção de uma literatura profundamente intertextual que cria debates internos e crítica do cânone, i.e., ao nível da própria tessitura dos textos literários; por meio da ludicidade linguística e da criatividade para a produção de uma língua inglesa pós-colonial de oposição; por meio de rejeição deliberada das religiões europeias, símbolos, alegorias, padrões e valores, em favor de culturas indígenas, práticas, histórias alternativas e sistemas de crença (incluindo narrativas fundacionais e personagens indígenas chave de figuras como a do malandro). (LANE, 2013, p. 487, tradução minha). ${ }^{8}$

Dentre todas as maneiras de respostas da literatura pós-colonial citadas por Lane (2013), o uso da língua europeia pelos escritores pós-coloniais talvez seja uma das mais polêmicas. Em Colonial and postcolonial fiction: an anthology, Robert L. Ross (2012) chama a atenção para o caso das ex-colônias britânicas e para o uso da língua inglesa. Nesse contexto, o autor afirma que muitos escritores explicam que a

8 "through production of a deeply intertextual literature that creates internal debates and criticism concerning the canon, i. e., at the level of the very fabric of literary texts; through linguistic playfulness and creativity to produce an oppositional postcolonial English language; through deliberate rejection of European religions, symbols, allegories, standards, and values, in favour of indigenous cultures, practices, alternative histories, and belief systems (including foundational narratives and key indigenous characters of figures such as the trickster)." 


\section{A literatura movente de Chimamanda Adichie}

língua é “adaptada, revista, colorida, torcida, sotaqueada, desfigurada, aumentada, e retrabalhada por seus usuários literários e não literários em todo o mundo” (ROSS, 2013, p. viii, tradução minha). ${ }^{9}$ A opinião de Ross corrobora o posicionamento de Chinua Achebe (1994), no conhecido artigo "The African Writer and the English Language”, em que o escritor defende o uso da língua inglesa pelos escritores africanos por questões práticas, como a impossibilidade de se aprender dezenas de línguas africanas diferentes, e pela visibilidade que uma língua mundial dá aos textos literários de escritores africanos.

Tal posicionamento, entretanto, encontra resistência. O queniano Ngugi wa Thiong'o (1986), em Decolonising the mind, elabora um argumento contrário ao de Achebe, defendendo que o escritor africano deve escrever em línguas africanas a fim de proteger sua cultura, sua memória, seus princípios e valores. Para o autor, o uso da língua do colonizador é uma forma de supressão cultural e uma continuação da dominação colonial, ensejando a mensagem de que as culturas dos colonizadores são superiores. Young (2003) também não vê com bons olhos o uso das línguas europeias nas ex-colônias, afirmando que línguas, assim como classes e nações, existem em hierarquia no contexto da pós-colonialidade. O autor faz essa constatação em meio à teorização de uma matéria que considera basilar na teoria pós-colonial: a tradução.

Fundamentando-se em Frantz Fanon, Young pondera que a ideia da tradução ultrapassa as questões textuais ou comunicacionais, motivando transformações geográficas e culturais, que envolvem perdas e ganhos, abrangendo assuntos de relações de poder:

A tradução se torna parte do processo de dominação, de se alcançar o controle, uma violência implementada sobre a língua, a cultura e sobre os povos que estão sendo traduzidos. As ligações mais

9 “....adapted, revised, colored, twisted, accented, disfigured, augmented, and reworked by its nonliterary and literary users around the world". 
próximas entre colonização e tradução começam não com as ações de troca, mas com as de violência e apropriação, de "desterritorialização”. (YOUNG, 2003, p. 140-1, tradução minha). ${ }^{10}$

Essa dominação de que fala Young (2003), que força a língua, a cultura e as próprias pessoas a um processo de tradução, durante e depois da colonização, encontra resistência, mas, historicamente, parece levar a uma nova condição que, mesmo sendo resultado de violência, apropriação e desterritorialização, passa a não ser uma questão de escolha dos indivíduos, algo contra o que se pode lutar. Tomemos como exemplo o uso da língua inglesa nas ex-colônias britânicas, como a Índia, assim como na diáspora indiana. Em Imaginary homelands, Salman Rushdie (1991) nos lembra de que o escritor indo-britânico não tem a opção de rejeitar o inglês: seus descendentes crescerão falando inglês, provavelmente como primeira língua. Nesse contexto, Rushdie utiliza a expressão "homens traduzidos" para se referir a pessoas de identidades hifenizadas, como a dele próprio, transferidas forçosamente de um lugar para outro, submetidas a uma outra língua e destituídas de seu lar. Contudo, diferentemente de Young, Rushdie pondera que, enquanto a maioria crê que todo processo de tradução significa um tipo de perda, ele acredita que ocorre também um tipo de ganho.

O ganho de que fala Rushdie tem a ver com o lugar intermediário ocupado pelo escritor em movimento, que lhe proporciona um olhar peculiar sobre o mundo, um olhar de perspicácia e relevância próprias, útil para que enxerguemos o mundo de novas maneiras. Esse lugar especial, que proporciona uma perspectiva igualmente peculiar, pode ser caracterizado pela condição híbrida das culturas pós-coloniais, cujo entendimento evoluiu de algo negativo, resultante da opressão e da dominação, para algo positivo, uma condição que passa a proporcionar empoderamento na inevitável configuração pós-colonial mundial. A noção de hibridismo cultural,

10 "Translation becomes part of the process of domination, of achieving control, a violence carried out on the language, culture, and people being translated. The close links between colonization and translation begin not with acts of exchange, but of violence and appropriation, of 'deterritorialization'.” 


\section{A literatura movente de Chimamanda Adichie}

por sinal, é muito cara aos estudos pós-coloniais. É descrita por B. Ashcroft et al. (2003) como "a criação de novas formas transculturais dentro da zona de contato produzida pela colonização" (ASHCROFT, 2003, p. 118, tradução minha). ${ }^{11}$ Ashcroft et al. (2003) ponderam que o processo é muitas vezes uma negociação consciente diante do choque cultural da colonização.

Em O local da cultura, Bhabha (1998) elabora a diferença entre as noções de hibridismo e hibridização. A primeira se refere à “impureza” que caracteriza todas as culturas: seria um engano, por exemplo, pensar o encontro de duas culturas, a de um colonizador e a de um colonizado, imaginando-as estáticas e puras. A hibridização é o permanente processo de transformação em que se encontram. Para Bhabha (1998), o hibridismo cultural é um modo de pensar que deseja romper binarismos e polarizações, como o opressor e o oprimido, o civilizado e o selvagem, o colonizador e o colonizado, considerados simplistas pelo autor. Para Young (1995), hibridismo é um "termo chave que, onde quer que apareça sugere a impossibilidade do essencialismo" (YOUNG, 1995, p. 159, tradução minha). ${ }^{12}$ Assim, pensando a partir de Ashcroft (2003), Bhabha (1998) e Young (1995), deve-se ver o estudo da colonização como o encontro de culturas em movimento, isto é, que já eram hibridizadas, o que evita equívocos oriundos de preceitos falaciosos como a pureza e a essência das culturas.

\subsection{A ideia de pós-colonialidade}

As discussões em torno dos temas língua, tradução e hibridismo cultural aqui feitas exemplificam marcas das sociedades vivendo na chamada pós-colonialidade, um termo substancial, mas que necessita ser delimitado em contexto, por apresentar diferenças de uso. Kwame Anthony Appiah (1991), por exemplo, faz um uso do termo de uma forma bem pessoal. Para o autor, a

\footnotetext{
11 “...the creation of new transcultural forms within the contact zone produced by colonization." 12 “...key term in that wherever it emerges it suggests the impossibility of essentialism."
} 
pós-colonialidade é a condição que nós poderíamos, de forma não generosa, chamar uma elite intermediária, um grupo de escritores e pensadores relativamente pequeno, treinados no Ocidente, que fazem a mediação do comércio em commodities culturais no capitalismo mundial na periferia. (APPIAH, 1991, p. 348, tradução minha). ${ }^{13}$

A ponderação de Appiah abre uma série de indagações, que podem problematizar, por exemplo, as ponderações de Gayatri Spivak (1994). Ela questiona se o sujeito pós-colonial mais oprimido dentre todos na escala entre o colonizador e o colonizado, por ela denominado subalterno, pode falar, isto é, se teria voz para se expressar no contexto em que o mundo se encontra. A resposta é não, o subalterno estaria desprovido dos meios de expressão e de posicionamento. Assim, de certa maneira, essa crítica de Appiah aos pensadores pós-coloniais de formação ocidental se volta contra a própria Spivak e outros teóricos do pós-colonialismo, cujo lócus de enunciação está situado em bases ocidentais, que influenciariam seus conceitos e reflexões teóricas pós-coloniais. Assim, depreende-se que a pós-colonialidade, no sentido atribuído por Appiah, é essa condição de teorização feita dentro de universidades do ocidente, por um grupo de pensadores privilegiados, o que, por consequência, excluiria o subalterno.

Rajagopalan Radhakrishnan (1996) também propõe uma definição de pós-colonialidade. De maneira semelhante a Appiah, o autor se incomoda com o uso do termo no meio acadêmico do Primeiro Mundo, temendo que a noção de pós-colonialidade seja "canonizada como uma constante universal pelos imperativos da teoria metropolitana” (RADHAKRISHNAN, 1996, p. 155, tradução minha).${ }^{14}$ Esse receio parte do fato de que os estudos pós-coloniais realizados na "metrópole”, isto é, em centros acadêmicos de países ocidentais, tratam da

13 “...postcoloniality is the condition of what we might ungenerously call a comprador intelligentsia: a relatively small, Western trained group of writers and thinkers, who mediate the trade in cultural commodities of world capitalism at the periphery."

14 "...canonized as a universal constant by the imperatives of metropolitan theory." 


\section{A literatura movente de Chimamanda Adichie}

“periferia” de maneira obsessivamente culturalista, desconsiderando aspectos econômicos, históricos e políticos, segundo Radhakrishnan (1996). O problema disso é que a cultura, nesse caso, é utilizada como uma agência universalista para falar de diversas sociedades, como se os estudos culturais isentassem intelectuais e teóricos de levarem em conta os “modos regionais de ser”, conforme expressão do autor. Dessa forma, o desafio, para Radhakrishnan (1996), está em elaborar um diálogo consistente com as muitas localidades que teriam algo a dizer sobre o “depois” da pós-colonialidade. Esse diálogo está ligado a matérias variadas referentes à heterogeneidade de identidades, de nacionalismos e de hibridismos. O autor constata que a "manipulação política de povos heterogêneos dentro da identificação do Estado-nação com o propósito de controle e dominação, infelizmente, cria distúrbios de longo prazo que permanecem profundos na fase pós-colonialista/nacionalista” (RADHAKRISHNAN, 1996, p. 159, tradução minha). ${ }^{15}$ Assim, trazendo identidade e nacionalismo como temas primordiais no debate da pós-colonialidade, Radhakrishnan (1996) estabelece uma pertinente, ainda que problemática, continuidade histórica entre colonialismo e nacionalismo e entre nacionalismo e diáspora. Esta última, como discuto mais adiante, servirá como abertura de possibilidades e melhor entendimento dos temas pós-coloniais.

Estabelecidas essas premissas, Radhakrishnan (1996) avalia que não pode haver uma articulação única de pós-colonialidade, de maneira que seria uma arrogância pedagógica falar “em nome da pós-colonialidade”, porque um único ângulo histórico não pode deter o controle monopolista das elaborações da questão pós-colonial. E completa que: “a pós-colonialidade como campo poderia ser a arena em que as desigualdades, os desequilíbrios e as assimetrias poderiam se historicizar 'de forma relacional', uma arena em que as historiografias dominantes poderiam ser explicadas pela autoridade ética e política das histórias emergentes” (RADHAKRISHNAN,

\footnotetext{
15 “...political gerrymandering of a heterogeneous people into nation-state identification for purpose of control and domination unfortunately creates long-term disturbances that last well into the postcolonialist/nationalist phase."
} 
1996, p. 171, tradução minha). ${ }^{16}$ Isso se constituiria em um universalismo no bom sentido, não coercitivo e de base justa, segundo o autor.

Em sua conclusão, Radhakrishnan expressa seu desejo de que a pós-colonialidade retenha um senso de espacialidade aberto para a ocorrência de transformações nas coalisões existentes, sendo a favor de uma alegorização da condição pós-colonial, desde que a alegoria esteja disponível como o espaço relacional a ser expresso de maneira heterogênea e relacional por posições de sujeitos minoritários oprimidos e subalternos em suas tentativas de buscar justiça e reparação de séculos de desigualdade.

As contribuições de Appiah (1991) e de Radhakrishnan (1996) são primordiais para esta obra, embora seja notório que eles priorizam a pós-colonialidade como um campo de estudos. Minha proposta é apreender a pós-colonialidade de outra forma, dentro da temporalidade histórica, vendo-a como parte significativa da condição mundial nos séculos XX e XXI, em que uma nova ordem se estabelece com as independências de países que se encontravam subjugados pelas nações colonizadoras da Europa. Essa dimensão da pós-colonialidade envolve todo o mundo, embora a demarcação histórica contemporânea induza a um recorte que privilegia os estudos de nações da África e da Ásia, cuja independência se deu mais recentemente. Há também quem venha a compreender a pós-colonialidade como uma condição anterior à independência, tendo começado durante a própria colonização.

Mas há autores que, como eu, compreendem a pós-colonialidade como fenômeno majoritariamente pós-independência, e o fazem porque desejam focar aspectos específicos, relativos às circunstâncias mais recentes. É claro que isso não dispensa o estudo das condições prévias e nem significa corroborar a noção de que a pós-colonialidade seria "um desejo por parte dos Estados-nações recentemente independentes de esquecer o passado colonial” (SIL, 2008, p. 23, tradução minha) ${ }^{17}$ conforme

16 "Postcoloniality as a field could well be the arena where inequalities, imbalances, and asymmetries could historicize themselves "relationally", an arena where dominant historiographies could be made accountable to the ethicopolitical authority of emerging histories."

17 "...a desire on the part of the newly independent nation-states to forget the colonial past." 


\section{A literatura movente de Chimamanda Adichie}

critica Narasingha P. Sil de maneira pertinente. Esse autor, em diálogo com teóricos pós-coloniais que discorrem sobre a memória, lembra que uma "amnésia forçada" de fatos coloniais dolorosos não se constitui em cura para elas, tendo em vista que não se pode tomar, de maneira deliberada, a decisão de esquecer os traumas da colonização. Além disso, Sil reafirma, citando Homi Bhabha (1994), que relembrar é um exercício fundamental na pós-colonialidade. A esse enfoque, acrescento que o ato de sufocar o passado colonial, ou qualquer passado, não apenas se constitui em um projeto impossível, mas também pode se revelar uma perigosa estratégia utilizada por novas classes dominantes surgidas nos períodos pós-independência, buscando poder sobre grupos unificados à força nos Estados-nações recém-criados.

Outro teórico que se dedica a desenvolver o conceito de pós-colonialidade é Biodun Jeyifo (1991). Em "For Chinua Achebe: the resilience and the predicament of Obierika”, o autor apresenta e caracteriza duas concepções antinômicas para a pós-colonialidade, como um exercício prévio que faz para desenvolver uma análise do romance Things fall apart, de Chinua Achebe. Para Jeyifo, há a pós-colonialidade da normatividade e designação proléptica e a pós-colonialidade intersticial e liminar. A primeira abordagem parte da premissa de que o escritor ou o crítico pós-colonial desenvolve seu discurso como representante de um novo Estado-nação independente, que é a reunião de uma grande comunidade nacional, multiétnica e multirracial, incluindo terras natais e diásporas. Esse discurso não raro prega como norma o retorno às raízes culturais por meio da "reafirmação ou reinvenção das tradições que o colonialismo, não sem considerável sucesso, havia buscado destruir ou desvalorizar” (JEYIFO, 1991, p. 53, tradução minha).$^{18}$ Nesse tipo de pós-colonialidade, conforme Jeyifo, há uma certa vigilância na inclusão de normas culturais e tradições consideradas confortáveis, baseadas em noções desgastantes de origens puras e de matrizes de um self não contaminado.

Como consequência, haverá, na pós-colonialidade da normatividade e designação proléptica, uma intenção, explícita ou não, de “ensinar” por meio dos escritos,

18 “...reassertion or reinvention of traditions which colonialism, not without considerable success, had sought to destroy or devalue." 
como se houvesse uma obrigação por parte de escritores de falar em nome de seus povos. Jeyifo acrescenta que, com a instauração de disputas, guerras civis e regimes autoritários após as independências, o projeto de falar em nome de outrem, oriundo da "dinâmica inebriante de luta pela descolonização", frequentemente resulta em desapontamento e desilusão.

A segunda abordagem de Jeyifo, que preconiza a pós-colonialidade intersticial e liminar, abarca a noção de sensibilidade híbrida, mais conhecida dentre os teóricos que atuam nas universidades de países ocidentais. Para Jeyifo, interstício ou liminaridade constituem o posicionamento ambivalente do escritor ou do crítico, que não estaria nem no Primeiro e nem no Terceiro Mundo, nem segura e presunçosamente na metrópole e tampouco assumindo a condição terceiro-mundista de forma assertiva e combativa. A forma com que tais escritores e críticos se definem revela a condição pós-colonial intersticial e liminar: diaspórica, exílica, híbrida, intersticial, cosmopolita. (JEYIFO, 1991, p. 53). Nesse caso, o escritor ou o crítico não apenas se recusa a falar em nome de outrem, mas também problematiza as polarizações centro e margem, metrópole e periferia, ocidental e não ocidental. Ademais, Jeyifo ressalta que, diferentemente da pós-colonialidade normativa e de designação proléptica, a pós-colonialidade intersticial e liminar não é monolítica, nem no corpus teórico que a define, nem em suas expressões literárias. Assim, essa perspectiva implica uma visão mais inclusiva e flexível de pós-colonialidade.

Por fim, vale lembrar que Ato Quayson (2000), ao comentar as pós-colonialidades de Jeyifo, ressalta que as duas tipologias desenvolvidas - a pós-colonialidade da normatividade e designação proléptica e a pós-colonialidade intersticial e liminar - não raro vêm justapostas e entrelaçadas em um mesmo texto. Portanto, não devem ser vistas como antagônicas e excludentes, mas como um continuum dialético.

Devo ressaltar que os aspectos das pós-colonialidades que reuni a partir dos trabalhos de Appiah (1991), Radhakrishnan (1996), Sil (2008) e Jeyifo (1991) são inspiradores, mas estão mais fortemente circunscritos a escritores, críticos e teóricos. A mim me instigam as pós-colonialidades dos cidadãos comuns, dos sujeitos 


\section{A literatura movente de Chimamanda Adichie}

pós-coloniais das mais diversas nações que foram colônias. Talvez seja pensando nessa linha que Radakrishnan (1996) pergunte, na introdução de seu capítulo sobre a pós-colonialidade, se ela seria um “estado geral de ser” ou uma experiência mais circunstancial, ocorrendo dentro de fronteiras geopolíticas específicas. Para fins de recorte teórico neste trabalho, devo esclarecer que a pós-colonialidade que tenho em mente está mais próxima desse “estado geral de ser”: é uma condição de milhões de indivíduos comuns e não apenas pesquisadores do meio acadêmico, habitando as mais diversas sociedades, isto é, a pós-colonialidade é uma condição humana. Assim, não faço uso do termo para me referir ao campo dos estudos, que tem sido definido de maneira bastante consensual como Estudos Pós-Coloniais. A pós-colonialidade que vislumbro tem forte influência da tipologia de Jeyifo (1991), em especial a pós-colonialidade intersticial e liminar, por ela ter um caráter mais aberto e heterogêneo, por considerar o hibridismo e a ambivalência e por destacar o deslocamento, seja diaspórico ou exílico, como parte da condição.

Desse modo, defino a pós-colonialidade como uma condição mundial contemporânea multifacetada, surgida a partir da extinção da colonização formal, em parte determinada pelo sistema mundial de Estados-nações, que se caracteriza pela presença persistente e até o reforço de preceitos e valores culturais disseminados por colonizadores, porém hibridizados de maneira complexa tanto com preceitos e valores pré-coloniais - que resistiram, apesar da violência da colonização -, como também com preceitos e valores contemporâneos de culturas terceiras. Em outras palavras, há, na pós-colonialidade, uma complexa justaposição espaço-temporal. A condição pós-colonial contemporânea é feita de uma tensa e permanente negociação, na qual ações e intenções, deliberadas ou não, influenciam a formação do indivíduo e das sociedades pós-coloniais de maneira diversificada, heterogênea e específica, tendo em vista que as colonizações, assim como os encontros entre duas ou mais culturas, nunca são idênticos uns aos outros. Também marca essa condição mundial contemporânea um cenário de intensa inquietude e mobilidade, que se dá nos deslocamentos e relocações, geográficos e físicos, mas também simbólicos e 
abstratos, oriundos da reconfiguração estabelecida pelo processo político de independência, que tornam ainda mais complexas as trocas e negociações culturais que ocorriam anteriormente.

\subsection{Descolonização e descolonização cultural}

Pensando a pós-colonialidade a partir dessa concepção, creio que seja imprescindível e profícuo encaminhá-la, discuti-la e associá-la com o conceito de descolonização cultural, que considero uma de suas consequências. O termo descolonização também tem sido usado há certo tempo, com acepções diversas. Em definições mais conhecidas, a descolonização tende a ser circunscrita ao processo histórico e político no qual uma colônia torna-se independente, após a saída do colonizador, adquirindo o status de país independente.

Tal ponto de vista dá origem a todo um debate de suma importância, como o que é feito por Albert Memmi em Decolonization and the decolonized (2006). Nesse livro, o autor discorre sobre o sujeito pós-colonial - o novo cidadão dos países que se tornam independentes, o imigrante e os filhos dos imigrantes - trazendo exemplos do mundo pós-colonial árabe-muçulmano. Mas muitas de suas considerações podem ser estendidas aos descolonizados de outras etnias e países. O diagnóstico de Memmi é pessimista: os recém-descolonizados almejam liberdade e prosperidade, mas se deparam com pobreza, guerras, desordem, tirania e todos os tipos de violência. O efeito é uma paralisia que afeta o povo de forma geral, inclusive os intelectuais. A falta de perspectivas, somada às expectativas frustradas, ocasionam uma debandada ao exterior, sobretudo de pessoas mais escolarizadas: "Certamente haverá mais intelectuais e escritores no exterior, de preferência no antigo país colonizador, do que na terra natal” (MEMMI, 2006, p. 69, tradução minha). ${ }^{19}$ Eles estão em busca de equilíbrio entre o silêncio, imposto por

19 "Surely, there will be more intellectuals and writers abroad, preferably in the former colonizing country, than in their homeland." 


\section{A literatura movente de Chimamanda Adichie}

regimes ditatoriais no país de origem, e o exílio, que, com todas as desvantagens, em geral permite ao intelectual que se expresse e denuncie.

Além de discorrer sobre a saída dos melhores talentos do país recém-independente, que representa um óbvio prejuízo para o desenvolvimento da nova nação, Memmi escreve sobre o imigrante descolonizado comum, que descobre novas frustrações por estar em terras estrangeiras, tanto na comunidade em que se instala quanto no país em geral. Ele é obrigado a encarar o que o autor denomina duplo fracasso: o da terra de origem e do da terra hospedeira.

Decolonization and the decolonized (2006) é uma obra com foco predominante nas questões políticas e sociais relativas ao processo de descolonização, aspectos significativos que excluem a ideia romântica de que, uma vez independente, a ex-colônia estaria automaticamente no caminho da liberdade e da prosperidade. Assim, a descolonização, vista como processual, se desenha como uma sequência contínua de fatos ou operações em andamento. A mesma noção de descolonização, ainda dentro do escopo histórico e político, pode ser estendida às ex-colônias fora do universo abordado por Memmi, onde também se observam longos processos de pós-independência, de disputas internas de poder, guerras civis e polêmicos projetos de estabelecimento de identidades nacionais como parte do que se convenciona chamar de descolonização. Essas matérias, pertinentes à pós-colonialidade, não são ocorrências isoladas do trauma colonial, mas são claramente sua continuidade. Não raro, as novas classes dominantes nas ex-colônias repetem nas nações recém-criadas um modelo europeu de relações de poder baseado na violência e na opressão de uns grupos sobre outros. Além disso, situações de dependência política e econômica das ex-colônias em relação às antigas metrópoles são recorrentemente estabelecidas.

Assim sendo, considerando os aspectos sociopolíticos e econômicos da descolonização, vinculados à história, pode-se inferir que o processo de se descolonizar está longe de ser considerado findo. E, se as questões sociopolíticas e econômicas nos dizem isso, o mesmo poderá ser dito sobre a descolonização em 
termos mentais e culturais, aspectos pouco trabalhados por Memmi, mas que gostaríamos de priorizar no contexto deste trabalho, com o auxílio de Edward W. Said. Em Cultura e imperialismo (1995), Said se dedica a rever, dentre outros tópicos, o papel da cultura na experiência imperial, uma relação, segundo o autor, difícil de ser feita, mas necessária. Ainda que o termo “descolonização” não pareça central no livro, Said contribui para essa noção ao avaliar que, mesmo que o colonialismo direto esteja praticamente extinto, o imperialismo sobrevive "numa esfera cultural geral, bem como em determinadas práticas políticas, ideológicas, econômicas e sociais” (SAID, 1995, p 40). O autor, que define o imperialismo como prática, teoria e ação de centros dominantes em territórios distantes, ao indicar sua existência pós-independência, abre-nos a perspectiva para considerar também a existência de uma espécie de colonialismo indireto, um colonialismo de ideias, já que, apesar de não haver mais a presença física do colonizador, observa-se sua presença simbólica, especialmente na cultura. Dessa forma, tal colonialismo estaria ligado ao imperialismo cultural.

Said pondera que a grande era do imperialismo está encerrada desde a entrega das maiores colônias, após a Segunda Guerra Mundial, mas “o significado do passado imperial” não se encerra apenas dentro desse período, "tendo se introduzido na realidade de centenas de milhões de pessoas, em cuja existência como memória coletiva e trama altamente conflituosa de cultura, ideologia e política ainda exerce enorme força” (SAID, 1995, p. 43). Para reforçar seu objetivo central no livro, que é a relação entre cultura e imperialismo, Said lembra que o poeta inglês William Blake, no século XIX, afirmou que "O Fundamento do Império é a arte e a Ciência. Retire-as ou Desgaste-as e não existirá mais Império. O Império segue a Arte, e não vice-versa, como supõem os Ingleses” (BLAKE, apud SAID, 1995, p. 44).

No contexto das ponderações de Said (1995), pode-se dizer que o processo de descolonização cultural em andamento lida com o que esse autor chama de resíduos do imperialismo, gerando uma série intensa de argumentos e contra-argumentos, que Said canaliza por meio da análise e da crítica literária, tanto 


\section{A literatura movente de Chimamanda Adichie}

das narrativas do homem e da mulher brancos quanto também daquelas produzidas pelos não brancos. Ao final de uma profunda análise do romance Coração das trevas, Said avalia que a visão eurocêntrica do autor Joseph Conrad, ainda que sua narrativa tenha trazido sérias críticas ao imperialismo, não conseguia vislumbrar a liberdade para os povos nativos africanos, como se não fossem capazes de uma vida livre da dominação europeia. Mas Said conclui lembrando que Conrad estava errado:

Existe todo um movimento, uma literatura e uma teoria de resistência e reação ao império [...] e nas mais díspares regiões pós-coloniais vemos um enorme esforço para se iniciar um debate com o mundo metropolitano em pé de igualdade, que mostre a diversidade e as diferenças do mundo não europeu e apresente suas prioridades, as coisas a fazer e suas próprias histórias. (SAID, 1993, p. 63-64)

São inúmeros os autores e as obras que compõem esse debate, em pé de igualdade, com o mundo metropolitano. Said menciona muitas delas, com destaque para as de Salman Rushdie, Derek Walcott e Chinua Achebe. Essa geração de autores foi capaz de ler e contestar grandes obras coloniais, respondendo a elas com sua própria produção literária. Na fase atual da produção literária pós-colonial, destacamos a autora nigeriana Chimamanda Ngozi Adichie, autora do romance Americanah (2013), publicado 20 anos após Cultura e imperialismo. Apesar de jovem, Adichie já figura na cronologia de eventos literários e políticos pós-coloniais da The Cambridge companion to the postcolonial novel, de Ato Quayson (2015).

No exame de Americanah, buscarei analisar como a descolonização cultural está representada no romance. Nesse contexto, defino a descolonização cultural como um processo, ${ }^{20}$ inerente à pós-colonialidade, no qual se buscam reposicionamentos que

${ }^{20}$ É de suma importância metodológica compreender a descolonização cultural como um processo em relação à pós-colonialidade, que foi por nós estabelecida como uma condição. Entendida como um processo, a descolonização cultural é uma ação ou realização continuada, em decurso, e, portanto, 
favoreçam indivíduos e sociedades vivendo na pós-colonialidade, no sentido de rever, amenizar ou mesmo extinguir os efeitos opressivos de preceitos e valores herdados da dominação colonial, que continuam exercendo controle sobre a mente, o espírito e a imaginação dos ex-colonizados, mesmo após a extinção da colonização formal. A descolonização cultural hoje não é o processo de resistência observado nos períodos pré e pós-independência, ou a quimérica recuperação da cultura pré-colonial, mas uma construção nova, que parte de inevitáveis aspectos da realidade pós-colonial, uma construção consciente das marcas não apagadas do colonialismo, mas capaz de criar novas formas híbridas de emancipação para indivíduos e sociedades pós-coloniais, posicionando-as de maneira mais autônoma e forte no contexto do século XXI.

\section{A pós-colonialidade na escrita de Adichie}

\subsection{Aspectos gerais}

Americanah é um romance que traz os sinais da contemporaneidade, ambientado em escala mundial, com personagens que transitam da África para a América do Norte e para a Europa. Os principais são Ifemelu e Obinze, nascidos na Nigéria, de onde emigram, ela para os Estados Unidos e ele para a Inglaterra, vivendo experiências típicas da pós-colonialidade. Deixam para trás sua jovem nação, a Nigéria, colonizada pelo Reino Unido do fim do século XIX até 1960, constituída de forma complexa por mais de 250 grupos étnicos, destacando-se os Ioruba, os Hauçá e os Ibo. A óbvia influência britânica, que permanece intensa mesmo após quase seis décadas de independência, pode ser exemplificada principalmente pelo idioma inglês,

inacabada. Como se pode verificar no dicionário Houaiss da Língua Portuguesa, a noção de processo é ligada à "sequência contínua de fatos ou operações que apresentam certa unidade ou que se reproduzem com certa regularidade; andamento, desenvolvimento, marcha” (HOUAISS, 2001, p. 2303). Já condição, que consideramos termo adequado para a pós-colonialidade, é sinônima de conjuntura, circunstância ou situação. Neste trabalho, deve ser entendida como "a circunstância que determina o caráter ou a existência de um fenômeno” (HOUAISS, 2001, p. 790). 


\section{A literatura movente de Chimamanda Adichie}

oficial no país, o cristianismo, o sistema educacional implantado pelos colonizadores e a própria criação do país, cujas fronteiras foram definidas ainda nos tempos da colonização, em 1914. A demarcação territorial forçada agregou reinos e etnias que nunca haviam se visto unificadas. Isso originou conflitos étnicos, religiosos e políticos que perduram até hoje, além da guerra civil de 1967 a 1970. O próprio nome do país foi sugestão de uma jornalista britânica no final do século XIX, derivado de Níger, nome do principal rio da região, que significa negro em latim.

Essa conjuntura histórica está refletida ficcionalmente nos tempos, espaços e personagens de Americanah, muito embora referências diretas aos conflitos religiosos e políticos, bastante divulgados pela mídia, não estejam no cerne da narrativa, como vemos, por exemplo, em "Uma experiência privada” (2009). Nesse conto, a protagonista Chika, uma Ibo cristã, se esconde em uma loja abandonada, em meio a um tumulto nas ruas de Lagos, em que cristãos e muçulmanos se enfrentam violentamente. No esconderijo, ela encontra uma mulher Hauçá muçulmana, com a qual inicia um diálogo e uma rápida relação. A experiência íntima revela o despropósito do conflito político-religioso que massacra inocentes de ambos os lados. Na confusão, as duas se perdem de parentes, mulheres também, e não sabem o que aconteceu com elas. Chika teme pela vida da irmã Nnedi e a muçulmana chora pela possibilidade de perder Halima, a filha. Naquele refúgio, elas se consolam, se cuidam, falam de suas famílias e de suas vidas. Subentendida, a mensagem final é a necessidade de uma tolerância étnico-religiosa que possa trazer tempos de paz, que possa superar a violência dos carros queimados, das cabeças cortadas, dos corpos pelas ruas, que espalham um odor de "carcaças de bodes [atiradas] na fogueira para que sua pelagem se queime” (ADICHIE, 2017, p. 52).

No tocante às questões linguísticas, as referências encontradas na escrita adichieana são bastante ricas. Em “A historiadora obstinada”, a autora trabalha o chocante encontro das culturas europeias dos colonizadores e a consequente imposição da língua inglesa na aldeia de Nwamgba, a personagem principal. Depois de perceber como os colonizadores estão, passo a passo, tomando o poder, tanto nas 
cidades quanto nas vilas ao redor da sua, Nwamgba matricula o filho na escola dos missionários para que possa aprender inglês. Ela havia resistido à essa ideia enquanto pôde, mas, como nos novos tribunais instalados pelos brancos a língua corrente é o inglês, ela não vê outra alternativa, pois teme que suas terras lhe sejam tiradas. Em pouco tempo, o filho Anikwenwa aprende o idioma, o que lhe confere autoridade na aldeia e enche Nwamgba de "um orgulho indulgente" (ADICHIE, 2017, p. 225). Junto com o inglês, porém, vem o ensino religioso, introduzindo noções como pecado, culpa, sacrifício e paganismo. Convertido ao catolicismo, Anikwenwa passa a rejeitar a cultura africana, tornando-se fanático, ansioso e, por vezes, agressivo. Assim, a escolaridade do filho de Nwamgba garante os papeis que certificam a posse das terras, mas a um alto preço: Anikwenwa agora "habitava um espaço mental que [...] era estranho” (ADICHIE, 2017, p. 226) a ela.

Nwamgba de "A historiadora obstinada” situa-se na virada do século XIX para o XX, servindo ao propósito de explicitar o princípio do trauma linguístico que foi a imposição do inglês. Em Meio sol amarelo (2008), romance que se passa no século XX, chama a atenção como Ugwu, adolescente que é empregado doméstico do professor universitário Odenigbo e sua namorada Olanna, admira o inglês falado pelos patrões: “O inglês do Patrão era música, mas o que Ugwu ouvia agora, dessa mulher [Olanna], era magia pura. Ali estava uma língua superior, uma língua luminosa, o tipo de inglês que ele escutava no rádio do Patrão, saindo com uma precisão cortante” (ADICHIE, 2008 p. 33). O contexto é a década de 1960, pouco depois da proclamação da independência da Nigéria. Ugwu é um garoto simples, vindo do interior, ao passo que seus patrões são letrados, dominam o idioma inglês, utilizando-o confortavelmente, como instrumento para seu próprio enriquecimento intelectual e também como ferramenta de trabalho, de maneira que para eles, o uso dessa língua não parece trazer os efeitos pesados da aculturação ou da opressão do colonizador. Já o fascínio de Ugwu pelo idioma, em especial pela forma como é falado por Odenigbo e Olanna, se explica pelo status que a língua adquire no país ao longo do século XX, o que se confirma por sua escolha como idioma oficial da 


\section{A literatura movente de Chimamanda Adichie}

nova nação, agora livre da presença física do europeu colonizador. Mas também pode-se dizer que parte do fascínio do jovem Ugwu pelo inglês vem de muitas décadas nas quais a cultura britânica, de maneira geral, se impôs aos africanos como civilizada e sofisticada, culminando com a situação presente da personagem, em que o inglês, em especial o “falado no rádio do patrão”, isto é, provavelmente por um locutor britânico, é um símbolo de ascensão social a ser buscado.

Em narrativas ambientadas no século XXI observa-se que o trauma permanece. Em “Réplica”, por exemplo, a bela dona de casa Nkem, casada com um homem rico, residindo com conforto nos Estados Unidos, “ainda misturava os tempos verbais ao falar inglês: porque ainda era, essencialmente, uma menina da roça” (ADICHIE, 2017, p. 39). Em “Os casamenteiros”, Chinaza é forçada a falar inglês pelo marido mesmo dentro de casa, o que para ela representa uma mudança ríspida que afeta sua identidade. Ela havia se submetido a um casamento arranjado e agora muda-se da Nigéria para os Estados Unidos, onde de fato vai conhecer quem é o marido. Ofodile é um nigeriano aculturado, que muda o próprio nome para Dave, obcecado por ser aceito pela sociedade estadunidense, e que passa a policiar Chinaza insistentemente: “Fale inglês, tem gente atrás de você” (ADICHIE, 2017, p. 190, tradução minha), repreende o marido, ao mesmo tempo em que corrige o vocabulário de Chinaza, forçando-a ao uso de palavras do inglês estadunidense, antes mesmo que ela tivesse tempo hábil para se adaptar.

Em Americanah, o inglês não é a única língua europeia citada. Madames ricas de Lagos sugerem a Obinze que “favoreça” sua filha matriculando-a na escola francesa, para que aprenda “outra língua civilizada” (ADICHIE, 2013, p. 28), já que o inglês é falado em casa. Outros sugerem que ele opte pela escola que ensina o currículo britânico completo, em detrimento do currículo nacional nigeriano. Em relação ao idioma de Shakespeare, o romance apresenta o tópico da língua como imposição, mas também como apropriação. A noção de uma língua imposta é ilustrada pelas gerações anteriores a Obinze e Ifemelu, educadas por missionários, que falam um inglês formal e elevado, como o pai de Ifemelu: 
... o inglês polido dele passou a incomodá-la quando ela ficou mais velha, porque era uma fantasia, seu escudo contra a insegurança. Ele era assombrado por aquilo que não tinha - uma pós-graduação, uma vida de classe média alta - e assim suas palavras afetadas se tornaram sua armadura. Ela preferia quando ele falava Ibo, era a única vez que ele parecia despreocupado de suas próprias ansiedades. (ADICHIE, 2013, p. 47-48, tradução minha). ${ }^{21}$

O pai de Ifemelu representa o nigeriano educado ainda no sistema dos colonizadores, pouco antes da independência, um sistema que priorizou o ensino do cristianismo, da língua inglesa, da história e dos valores britânicos, ignorando as culturas africanas. A mensagem principal da escola colonial era a de que o modo de vida local era primitivo, indigno mesmo de ser citado, ao passo que a cultura e os valores britânicos eram civilizados e, em consequência, os únicos que deveriam ser estudados. Assim, o pai de Ifemelu cresce na expectativa do sucesso que o aprendizado da língua e da cultura inglesa prometem, mas que não se realiza, resultando nessa ansiedade de que fala a narradora.

Em contrapartida, Ifemelu e Obinze representam uma geração nascida após a independência, que estuda em um currículo escolar reformulado, demonstrando uma atitude mais prática e menos traumática em relação à língua inglesa. O uso dessa língua não lhes causa ansiedade, não julgam o inglês como língua superior e nem consideram a cultura britânica mais civilizada. Namoram em Ibo, às vezes em inglês, alternando entre as línguas de maneira natural, declamando provérbios africanos um ao outro.

Além da abordagem das línguas como pressuposto cultural híbrido na Nigéria contemporânea, em negociação permanente no interior dos indivíduos e da

21 “... his mannered English bothered her as she got older, because it was a costume, his shield against insecurity. He was haunted by what he did not have - a postgraduate degree, an upper-middle-class life - and so his affected words became his armor. She preferred it when he spoke Igbo, it was the only time he seemed unconscious of his own anxieties." 


\section{A literatura movente de Chimamanda Adichie}

sociedade, Americanah também desenha o cenário da inquietude que caracteriza a pós-colonialidade, conforme discuti. A mobilidade que é, conforme Cresswell (2006), ubíqua no cenário atual, apresenta-se em vários níveis no romance: deslocamentos locais constantes, no ambiente urbano; relocações internas à Nigéria, de uma cidade à outra; viagens de turismo a lugares como "Cozumel por uma noite, Londres por um fim de semana prolongado” (ADICHIE, 2013, p. 209, tradução minha), ${ }^{22}$ feitas por Ifemelu e o namorado Curt; e as imigrações entre continentes, que atingem desde as personagens secundárias, como as cabeleireiras africanas do salão de beleza em Trenton, quanto as principais, como Obinze, que vai para a Inglaterra, e Ifemelu, que vai para os Estados Unidos. Os protagonistas, ambos estudantes universitários na Nigéria, têm os estudos interrompidos por greves intermináveis, durante um governo militar, o que os leva, junto com outros milhares de jovens, a emigrar para continuarem os estudos fora, principalmente nos Estados Unidos e na Inglaterra. Quando os amigos só falavam em partir, Ifemelu decide se mudar para a Filadélfia, estimulada por uma bolsa de estudos, e por sua tia, que já estava nos EUA. Ifemelu parte com um visto de estudante, válido por alguns anos, ao contrário de Obinze, cujo visto de permanência é de apenas seis meses.

A complexidade dessa teia de experiências de mobilidade em Americanah está além dos diferentes níveis, que vão do local ao global, está no modo como ocorrem subliminarmente, determinando formas de ver o mundo e ações. Nos termos de Cresswell (2006), autor que citei no capítulo 1, a teia das experiências de mobilidade seria formada pelo jogo entre as metafísicas "sedentarista" e nômade, sendo, simultaneamente, uma indicação de dinamismo e progresso e também de incerteza e desordem. Por exemplo, ao mesmo tempo em que testemunhamos o sucesso alcançado por Ifemelu nos Estados Unidos, vemos o fracasso de Obinze na Inglaterra. Ele somente é bem-sucedido na Nigéria, após o retorno, de maneira que, pelo menos no caso desse exemplo, o romance tende a reforçar uma visão

\footnotetext{
22 “Cozumel for one night, London for a long weekend.”
} 
de mundo pelas "lentes do lugar", pelo enraizamento e pelo pertencimento, o que caracteriza a metafísica "sedentarista”, conforme Cresswell (2006).

Embora as situações tenham suas particularidades, Ifemelu e Obinze enfrentam condições semelhantes de discriminação racial, preconceito, perda, dificuldades de adaptação e de empregabilidade, isolamento e saudades. Essas questões, decorrentes da experiência de mobilidade transcontinental, são centrais no romance, ensejando uma condição pós-colonial de tensão entre passado e presente e de intensas negociações entre abandono, manutenção ou reapropriação de valores culturais, sejam nigerianos, ingleses ou estadunidenses. No turbilhão da pós-colonialidade que caracteriza todas as dimensões em Americanah, chamam-nos a atenção as estratégias de representação do processo de descolonização cultural articuladas por Adichie, centralizadas na protagonista Ifemelu.

Em linhas gerais, a descolonização cultural, como vimos, refere-se à adoção de novos posicionamentos que venham a beneficiar o sujeito pós-colonial, de maneira que possa elaborar os efeitos opressivos da colonização que, na Pós-colonialidade continuam existindo na mente, no espírito e na imaginação. Pode-se afirmar que, de maneira explícita ou não, a descolonização cultural está presente nos projetos dos escritores pós-coloniais do século XXI, incluindo Chimamanda Adichie, conforme se observa em sua obra literária. Em Americanah, não apenas Ifemelu e Obinze lidam com as próprias questões de autoestima e reposicionamento, mas também os outros personagens nigerianos da narrativa, cada um a seu modo. Nesta análise, desenvolverei uma abordagem bastante específica sobre como a descolonização cultural é trabalhada no texto literário por meio de um dos temas centrais na narrativa: o cabelo afro da mulher negra.

Tema que a princípio pode ser considerado inusitado ou trivial, o cabelo da mulher negra, notadamente a que vive nos Estados Unidos, é abordado com certa frequência por Adichie. Em "Réplica” (2017), o marido empresário de Nkem, Obiora, acredita que a esposa de um "grande homem” deve ter cabelo comprido. Então ela o mantém longo para agradá-lo, assim como tudo mais em seu casamento, 


\section{A literatura movente de Chimamanda Adichie}

feito para a satisfação do chefe da casa. Mas Nkem descobre que Obiora tem uma amante jovem, de cabelos curtos e crespos, tratados com um texturizador e não com um relaxante. Por semanas, ela pensa no assunto, pesa os prós e contras de um possível divórcio e toma uma medida relacionada ao cabelo:

Ela pega a tesoura, aquela que usa para cortar as fitas de cabelo de Adanna em laços mais definidos, e leva até a cabeça. Agarra tufos de cabelo e corta rente ao couro cabeludo, deixando os fios do comprimento de uma unha, longos o suficiente apenas para formar pequenos cachos com um texturizador. Nkem vê o cabelo flutuando, como tufos de algodão marrom caindo na pia branca. Ela corta mais. Mechas de cabelo voam para baixo, como asas chamuscadas de mariposas. Ela enfia a tesoura mais fundo. Mais cabelo sai flutuando. Alguns fios caem em seus olhos fazendo-os coçar. (ADICHIE, 2017, p. 35-36).

O ritual descrito na passagem acima possui significados e implicações profundas. Obiora volta de uma viagem e se surpreende com o cabelo da esposa. Aparentemente, Nkem apenas estaria desejando imitar o estilo da amante do marido, parecer tão jovem quanto ela, mas o intrigante desfecho de "Réplica” revela mais que isso. Nkem decide que não quer se separar e lida de forma astuta com a situação: por meio do novo corte de cabelo, do qual Obiora não gosta, ela se impõe ao marido de maneira inédita, lembrando-o, em entrelinhas, de seus direitos de esposa e mãe de seus filhos e insinuando que sabe da traição, mostrando que tem domínio da situação e que não está mais disposta a fazer todas as suas vontades.

Mas em Americanah (2013) o tema do cabelo afro da mulher negra é abordado com maior profundidade. Adichie o eleva a uma expressão política de identidade, de raça e de gênero, demonstrando que o cabelo está relacionado à autoestima e à emancipação da mulher negra. É, por conseguinte, um assunto que traz o feminismo à discussão pós-colonial. A principal contribuição do feminismo pós-colonial talvez seja a demonstração de que há uma significativa diferença entre a luta pela 
emancipação desenvolvida pela mulher branca europeia e estadunidense e aquela a ser concebida pela mulher de cor, especialmente as de países pós-coloniais. A esta mulher coube o fardo da "dupla colonização", como teorizam Petersen e Rutherford, ao avaliarem que a mulher na colonialidade e também na pós-colonialidade é vítima de um processo duplo de opressão, pelo colonizador e pela família, comandada pelo homem colonizado.

\subsection{Um aspecto específico}

\subsubsection{Fingindo ser outro: identificações problemáticas}

O dilema identitário na pós-colonialidade surge logo na abertura de Americanah (2013), quando a narradora descreve o campus da Universidade de Princeton, segundo o gosto da protagonista Ifemelu: as árvores, os edifícios e lojas são agradáveis, fazem-na se sentir em paz, mas Princeton é, acima de tudo, um lugar em que "ela poderia fingir ser outra pessoa, alguém especialmente aceito em um clube americano sagrado, alguém enfeitado de certeza” (ADICHIE, 2013, p. 3, tradução minha). ${ }^{23}$ É relevante que as primeiras palavras do romance façam alusão ao campus universitário como um ambiente que, por um lado, favorece Ifemelu, por lhe trazer tranquilidade e conhecimento. Vinda da Nigéria, Ifemelu obteve uma bolsa de estudos, mas o exame detalhado de sua condição de imigrante revela uma experiência de impasses, conflitos e constrangimentos em solo estadunidense. Princeton como "clube americano sagrado" implica o elitismo de uma organização fechada, voltada para americanos, na qual ela apenas pode fingir que é aceita.

Dessa passagem o leitor também infere que a vontade da protagonista de ser outra pessoa, alguém “adornado de certeza”, prenuncia uma narrativa a revelar as dúvidas mais íntimas de uma mulher cujo desejo de fingir ser outra sugere uma

23 “...she could pretend to be someone else, someone specially admitted into a hallowed American club, someone adorned with certainty." 


\section{A literatura movente de Chimamanda Adichie}

insatisfação ou necessidade de aliviar a pressão identitária que recai sobre si mesma, exercida pela comunidade a seu redor. Ifemelu, de fato, sente dificuldade em ser ela mesma nos Estados Unidos, representando o imigrante e seu típico problema de pertencimento à sociedade que o recebe. Essa dificuldade tem consequências diretas sobre a autoaceitação, a autoestima e a autodefinição. Lançados assim, na abertura da narrativa, esses temas funcionam como uma espécie de teaser, um provocador de indagações: o que leva um indivíduo a um comportamento de "fingimento identitário”, isto é, querer se passar por ou mesmo ser outro? Quais são os obstáculos que dificultam a aceitação de Ifemelu nos Estados Unidos?

No parágrafo seguinte, a narradora muda o tom da descrição dos aspectos agradáveis do ambiente universitário para relatar a insatisfação de Ifemelu por ter de ir fazer o cabelo em Trenton, um bairro distante, pois em Princeton não há salões especializados em cabelos de mulheres negras. Ela deseja fazer o braiding, que é trançar o cabelo no estilo afro, e segue no trem refletindo que a ausência desse tipo de salão em Princeton se deve ao fato de que, além de haver poucas mulheres negras na universidade, elas todas alisam o cabelo. Os pensamentos de Ifemelu introduzem um tema central em Americanah: o cabelo da mulher negra, tanto a africana quanto a afro-americana. Assim como a cor da pele, o cabelo é, por assim dizer, derivado dos temas raça e racismo, novos para Ifemelu: somente ao chegar nos EUA ela se dá conta de que é negra, já que cor da pele e raça são assuntos que não fazem muito sentido na Nigéria, um país de população essencialmente negra. $\mathrm{O}$ assunto a intriga e se torna motivação para que ela comece a escrever o blog Observações curiosas de uma negra não americana sobre a questão da negritude na América (tradução minha), ${ }^{24}$ que a torna famosa, pois o blog adquire popularidade. O blog de Ifemelu, por sinal, pode ser entendido como uma estratégia de inserção de voz de Adichie em seu próprio romance, uma janela que se abre para contendas de teores polêmicos ligados aos temas raciais na sociedade estadunidense.

24 "Curious observations by a non-American black on the subject of blackness in America." 
Durante o percurso para Trenton, o leitor tem acesso a outras memórias e reflexões de Ifemelu, como o contexto em que veio para os EUA e o porquê de sua decisão em trançar o cabelo: ela havia decidido retornar ao país de origem. A decisão envolve assuntos pessoais, como o fim do relacionamento com o professor universitário Blaine, bem como a possibilidade de reencontro com Obinze, namorado dos tempos de estudante na Nigéria, assim como questões sociais mais abrangentes, sobre a readaptação na Nigéria e o abandono das comodidades a que se havia acostumado na sociedade estadunidense. Quando Ifemelu desce do trem e busca um táxi, o tema do fingimento identitário retorna. Ele espera que o motorista não seja nigeriano: “Os taxistas nigerianos nos Estados Unidos eram todos convencidos de que não eram realmente taxistas" (ADICHIE, 2013, p. 8, tradução minha). ${ }^{25}$ Ela pensa isso porque era comum que eles contassem histórias pouco prováveis de mestrados que fizeram e de filhos na faculdade. $\mathrm{O}$ fato de assumirem nomes americanos também reforça esse comportamento.

Esses taxistas descritos pela narradora, com sua tendência para criar histórias ou simular, assemelham-se a mitômanos e, de certa forma, eles aborrecem Ifemelu não apenas por suas invencionices, mas porque a lançam em uma perspectiva de espelhamento no qual ela se vê: ela também deseja, ainda que por alguns momentos, ser outra pessoa; ela também, em algumas ocasiões, mente sobre si mesma. Ao notar os nomes americanos adotados pelos taxistas, colocados em pequenas placas dentro dos táxis, Ifemelu se lembra de que ela também havia sido "outra pessoa" ao utilizar identidade falsa para conseguir emprego, conforme descreve o narrador. Seu visto era de estudante e, embora tivesse bolsa de estudos de 75\%, precisava trabalhar para pagar o restante. A adoção de nomes americanizados por imigrantes, comum nos Estados Unidos, é, por sinal, bastante simbólica no que se refere ao que tenho denominado fingimento identitário.

Tem-se, no caso especial de Ifemelu e dos taxistas nigerianos, uma categoria específica de indivíduos em um comportamento de fingimento identitário: o sujeito

25 "Nigerian taxi drivers in America were all convinced that they really were not taxi drivers." 


\section{A literatura movente de Chimamanda Adichie}

pós-colonial diaspórico. Adichie amplia o escopo do debate: todos são imigrantes, todos vêm da Nigéria e, portanto, todos carregam as marcas do presente diaspórico e do passado colonial. Esta última característica nos remete à obra de Franz Fanon, que ajuda a entender o fingimento identitário. No conhecido livro Black skin, white masks, publicado em 1952, Fanon avalia os efeitos extremamente prejudiciais do racismo colonial na mente do negro, causador, dentre outras coisas, de uma assimilação cultural e de um complexo de inferioridade. A mensagem do colonizador de que a negritude é impura e má gera uma negação da identidade negra e uma impossível aspiração de ser branco. O colonizado, através do tempo, internaliza que o conceito de ser humano é ser branco, vendo-se então como sub-humano, alguém em um dilema eterno de tentar ser aquilo que não é. Trazendo essa lógica perversa para Americanah, a situação de sujeitos pós-coloniais como Ifemelu e os taxistas nigerianos é agravada na diáspora. Ao imigrarem, têm a expectativa de se libertarem das amarras coloniais mentais e sociais, mas o movimento concreto de saída de um espaço opressor para outro não necessariamente representa o fim da opressão, podendo trazer a frustração de novos desafios, como a triste descoberta de que há novas formas de ser inferiorizado no país que o recebe. Essa conjuntura pode ser equacionada com o que Albert Memmi (2006) denomina duplo fracasso, como vimos antes, aplicando-se mais aos taxistas do que à Ifemelu que, no final das contas, é bem-sucedida em seus projetos no exterior.

Creio que caiba aqui um aparte ao tema da identidade do sujeito pós-colonial diaspórico para uma breve avaliação do simbólico itinerário da imigrante Ifemelu, de Princeton a Trenton, como "movimentos dentro do movimento", que se tornam ainda mais notáveis por se situarem na abertura do romance. O percurso de trem, complementado pelo de táxi, são mais que deslocamentos do dia a dia: estão carregados das marcas do cenário de mobilidade da pós-colonialidade, enriquecidos pelas reflexões de uma imigrante em sua inquietude. Eles também remetem aos sistemas de mobilidade descritos por John Urry (2011). Como mencionei no capítulo introdutório, a cadeia de sistemas de mobilidade e suas interposições complexas estão 
mais disponíveis em sociedades mais ricas; o itinerário de Ifemelu, em uma cidade estadunidense, simboliza seu acesso a um mundo com mais opções. Ademais, os sistemas de mobilidade também têm relação com a desigualdade social, segundo Urry. Assim, no exemplo de Americanah, é possível inferir, a partir do princípio da narrativa, que Ifemelu, tendo acesso a um sistema de mobilidade como o que foi descrito, está em condição melhor que outros imigrantes, como, por exemplo, as cabeleireiras africanas do salão de beleza.

Findo o itinerário, Ifemelu chega ao Mariama African Hair Braiding. O salão fica em uma região de edifícios antigos, pichados, onde não se veem brancos. Ela conhece bem esses estabelecimentos, com suas revistas de beleza feminina, com aquecedores que aqueciam demais no inverno e aparelhos de ar-condicionado que não esfriavam o suficiente no verão. A temperatura interior é desregulada assim como as relações das mulheres que ali trabalham, sejam as relações delas consigo mesmas, com suas famílias e parceiros e também com sua terra natal e com a terra hospedeira. As cabelereiras que trançam, chamadas de braiders, são mulheres africanas francófonas, de países como Mali e Senegal, que conversam alto em francês, malinke ou wolof, mudando de assunto de maneira brusca, às vezes usando um inglês macarrônico e fragmentado "de palavras que saíam pela metade” (ADICHIE, 2013, p. 9, tradução minha), ${ }^{26}$ somente para se dirigir à clientela.

Em entrevistas, Adichie já discorreu sobre o fascínio que tem por ambientes como o salão de beleza, para ela verdadeiros laboratórios de preparação de sua ficção. O salão Mariama African Hair Braiding, obviamente inspirado em lugares já visitados pela autora, é um ambiente multicultural que proporciona um encontro de culturas típico da contemporaneidade, com mulheres que se veem obrigadas a um reposicionamento identitário, comum nas diásporas, objetivando a própria sobrevivência; é um espaço que serve para revelar desafios e dissabores de suas vidas. Elas falam de assuntos diversos, suas relações amorosas, revelam suas fragilidades

26 “...words came out half-completed." 


\section{A literatura movente de Chimamanda Adichie}

diante dos filmes de Nollywood ${ }^{27}$ que assistem, propagadores do amor romântico e do casamento como finalidade única da mulher, filmes "com histriônica exagerada e seus enredos improváveis” (ADICHIE, 2013, p. 13, tradução minha), ${ }^{28}$ como comenta Ifemelu, dentre outras coisas.

\subsubsection{O cabelo de Ifemelu: tingir, alisar e trançar}

É no Mariama African Hair Braiding, espaço típico da transformação feminina e propício aos questionamentos identitários, que Ifemelu vai passar por três etapas: tingimento, alisamento e "trançamento" de seu cabelo. A primeira delas, o tingimento, inicia um debate central no romance sobre a relevância do cabelo para a identidade feminina, em especial para a mulher negra. A cabeleireira Aisha, imigrante senegalesa, designada para atender Ifemelu, começa por perguntar a cor que a cliente deseja para o aplique, mas, ao ouvir a resposta, cor 4, afirma prontamente não se tratar de uma cor boa, determinando que ela deve usar a cor 1, porque a 4 deixa o cabelo com "aparência de sujo”. Ifemelu então responde: “A cor 1 é preta demais, fica artificial [...] às vezes uso a cor 2, mas a 4 é a mais próxima do meu cabelo natural” (ADICHIE, 2013, p. 12, tradução minha). ${ }^{29}$ Dois pontos de vista distintos aqui são revelados: na opinião de Aisha, o aplique de cor número 4, próximo do natural, parece sujo, sugerindo que a cabeleireira tende a depreciar as características naturais do cabelo afro. Ifemelu, ao contrário, argumenta que a tintura mais forte deixa o aplique com aparência artificial, optando por uma coloração mais próxima do natural.

Dessa solicitação, é possível deduzir que Ifemelu traz um grau maior de aceitação de seu cabelo e, por tabela, de sua negritude. Para o entendimento dessa primeira divergência entre elas, é necessário levantar o histórico das duas mulheres:

\footnotetext{
27 “Nollywood” é uma denominação popular para a indústria cinematográfica nigeriana, que faz referência ao termo "Hollywood".

28 "...exaggerated histrionics and their improbable plots."

29 "Color one is too black, it looks fake [...] Sometimes I use color two but color four is closest to my natural color."
} 
Ifemelu, a narrativa revela, é uma jovem universitária, observadora das questões sociais, blogueira ativista sobre a negritude em terras estadunidenses, muitas vezes assumindo um discurso político sobre o empoderamento de si mesma e de outras mulheres negras. Em contrapartida, Aisha é uma mulher simples, de pouca escolaridade, cujos parâmetros de beleza feminina sãos as revistas empilhadas no canto do salão, que estampam modelos brancas em suas páginas. Sem muitos recursos para a autoconscientização, Aisha passa o dia pensando em convencer o namorado a se casar com ela e assistindo a comédias românticas de Nollywood.

A segunda "sugestão" de Aisha para Ifemelu é um produto alisante. A protagonista, de maneira astuta, retruca de imediato que prefere o próprio cabelo "do jeito que Deus fez". A resposta de Ifemelu tem um motivo: ela tem experiência sobre salões de beleza e sobre como pensam as braiders. O argumento "Deus fez" é utilizado como uma tentativa para encurtar o diálogo com a insistente Aisha, uma estratégia para encerrar o assunto, visto que o argumento “Deus” normalmente não é posto em dúvida. Aisha, porém, acostumada a convencer suas clientes, não se dá por vencida, e pergunta como ela faz para pentear. Ifemelu então tira da bolsa o próprio pente, adequado para seu tipo de cabelo e, com gestos de carinho, começa a penteá-lo com gestos delicados:

... até que emoldurasse sua cabeça como uma auréola. "Não é difícil de pentear se você o hidratar corretamente”, disse ela, resvalando-se para o tom persuasivo de pregador que ela usava sempre que estava tentando convencer outras mulheres negras sobre os méritos de se usar seu cabelo natural. Aisha bufou; ela claramente não conseguia entender por que alguém iria optar por sofrer penteando o cabelo natural, em vez de simplesmente fazer o alisamento. (ADICHIE, 2013, p. 12-13, tradução minha). ${ }^{30}$

30 “... until it framed her head like a halo. "It's not hard to comb if you moisturize it properly," she said slipping into the coaxing tone of the proselytizer that she used whenever she was trying to 


\section{A literatura movente de Chimamanda Adichie}

A assertividade de Aisha de que o alisamento é a melhor, senão a única solução para o cabelo afro problematiza o conceito de beleza vigente nos salões, evidenciando a predominância do cabelo liso como padrão ideal a ser seguido pelas mulheres negras. A cabeleireira não apenas pensa dessa forma, mas deseja impor sua opinião às clientes negras. Essa noção do cabelo liso como padrão de beleza, internalizada por muitas mulheres negras como Aisha, constitui um exemplo relevante de como uma característica europeia viaja o mundo no processo de colonização, juntamente com muitos outros discursos de solidificação da supremacia do colonizador europeu, para ser estabelecida como superior. Isso se dá com o suporte da representação cultural, conforme assinalamos no argumento de Bhabha (1998), na qual verificam-se forças desiguais e irregulares na competição pela autoridade política e social no mundo. Assim, o cabelo liso da mulher branca se torna o "cabelo bom”, em detrimento de todos os outros tipos, e essa questão, por conseguinte, se configura em um tema próprio da pós-colonialidade, tendo em vista que se funda na existência de um aspecto feminino de origem europeia que influencia a mulher negra a partir da colonização a ponto de causar rejeição de um traço típico da negritude, que é o cabelo afro natural.

Além disso, o tema do cabelo afro ajuda a ilustrar a diferença entre a luta do feminismo dito ocidental, voltado para a mulher branca, e o feminismo negro, porque demonstra como a autoestima e a emancipação das mulheres negras passam por demandas específicas que decerto não constituem dificuldade para as brancas. Assim, pode-se dizer que o feminismo negro reivindica igualdades distintas de condições que se acumulam desde antes da chegada do colonizador até a pós-colonialidade. Particularmente no caso nigeriano, Maria Rojas (2016), ao discutir o trabalho de Niara Sudarkasa, atenta para o fato de que as mulheres, nas sociedades nigerianas pré-coloniais, sofriam um tipo de controle que as limitava ao espaço

convince other black women about the merits of wearing their hair natural. Aisha snorted; she clearly could not understand why anybody would choose to suffer through combing natural hair, instead of simply relaxing it." 
doméstico e valorizava sobretudo sua fertilidade, e que tinham um papel profissional complementar ao do homem. Rojas ressalta, entretanto, que o papel complementar é muito diferente do subordinado, tendo em vista que na Nigéria pré-colonial o poder não estava ligado ao gênero, mas à senioridade. Adichie parece concordar com esse ponto de vista ao afirmar, em entrevista ao canal News Exclusive, em 8 de agosto de 2016, que sua bisavó constitui seu modelo pessoal de feminismo e não os famosos movimentos feministas ocidentais. A autora conta que a bisavó viveu em uma Nigéria pré-cristã em que os papéis de gênero não eram tão rígidos quanto agora:

Há muitas coisas sobre os papéis de gênero na Nigéria hoje que são o resultado de um tipo de cristianismo vitoriano que herdamos dos missionários. Então, na verdade, examinar aquele passado é inspirador para mim porque é um dos modelos a se olhar para se pensar sobre como gênero é algo que nós construímos. (ADICHIE, 2016, tradução minha). ${ }^{31}$

O comentário de Adichie nos permite depreender que a religiosidade trazida pelo colonizador inglês, por meio dos missionários cristãos, está imbuída de conceitos de gênero que não existiam até então, cujos papéis pré-definidos não favorecem a mulher africana. Outro ponto observado pela autora de Americanah diz respeito à noção de gênero como construto social, uma ideia que significou grande avanço nos estudos de gênero, mas que precisa ser aprofundada: hoje é imprescindível constatar que gênero, além de ser uma construção, é constituído de formas diferentes em cada cultura e, portanto, a luta pela igualdade também será

31 "There's a lot about gender roles in Nigeria now that are the result of the kind of Victorian Christianity that we inherited from the missionaries. So actually looking back at that past for me is inspiring because it's one of the models to look at to think about how gender is something we construct”. Disponível em https://www.youtube.com/watch?v=ARhgbpYLggg. 


\section{A literatura movente de Chimamanda Adichie}

específica, como se pode ver a partir da polêmica sobre o cabelo afro - natural ou alisado - em Americanah.

Finalmente, Aisha inicia as tranças no cabelo de Ifemelu, mas as divergências entre ambas continuam. A cabeleireira puxa o cabelo com força, fazendo as tranças muito apertadas, de maneira a causar dores na cliente. Ifemelu reclama, pedindo para afrouxar, mas Aisha a ignora, declarando que está bom daquele jeito, insistindo em fazer à sua maneira. Mas a dona do salão intervém, ordenando que a trança seja desfeita e reiniciada, dirigindo-se apologeticamente à cliente: ““Desculpe’, Mariama disse. ‘Ela não entende muito bem’” (ADICHIE, 2013, p. 13, tradução minha). ${ }^{32}$ Mas Ifemelu percebe, pelas feições de Aisha, que ela de fato havia compreendido, e a cizânia não era de causa linguística. Ifemelu, então, reflete sobre o comportamento rude de Aisha, atribuindo a indelicadeza à sua provável origem humilde, uma mulher que desconhecia as "cortesias do serviço ao cliente no padrão estadunidense”:

Ifemelu a imaginou trabalhando em um mercado em Dakar, como as braiders em Lagos que assoavam o nariz e limpavam as mãos em suas batas, virando a cabeça de suas clientes grosseiramente para melhor posicioná-las, reclamando do quanto o cabelo era cheio, ou que era duro ou curto demais, gritando com outras mulheres que por ali passavam, enquanto conversavam alto demais e trançavam apertado demais. (ADICHIE, 2013, p. 13, tradução minha). ${ }^{33}$

Como já apontado, Ifemelu é uma mulher que conhece bem o ambiente de salões de beleza para mulheres negras, com cabeleireiras vindas de países africanos, imigrantes humildes que, como Aisha, parecem não estar preparadas para lidar com a clientela de maneira profissional. Entretanto, se a percepção inicial de

\footnotetext{
32 "Sorry, Mariama said. She doesn't understand very well."

33 "Ifemelu imagined her working in a market in Dakar, like the braiders in Lagos who would blow their noses and wipe their hands on their wrappers, roughly jerk their customers' heads to position them better, complain about how full or how hard or how short the hair was, shout out to passing women, while all the time conversing too loudly and braiding too tightly."
} 
Ifemelu alude ao tratamento oferecido aos clientes nas relações comerciais típicas do ambiente capitalista estadunidense, sua imaginação vai além, fazendo-nos pensar em outros motivos para o comportamento de Aisha. Assim, essa passagem remete, por exemplo, a uma declaração da própria autora, no International Authors' Stage, Dinamarca, em que ela conta que é parte de suas observações em salões de beleza, tanto em Lagos como em outros lugares, a existência de diferentes níveis de "maldade de mulher para mulher" (ADICHIE, 2014). Dessa forma, talvez se possa inferir que as braiders da África e suas clientes, como mulheres que tratam mal outras mulheres, apresentam um comportamento que no fundo é resultante de estruturas sociais patriarcais nas quais a própria mulher transmite valores e atitudes opressivas, ensinando desde cedo às meninas a competirem com outras, forçando comportamentos e cobrando padrões de beleza umas das outras.

Outra inferência possível sobre a rudeza da cabeleireira pode ser feita pela crença de que beleza feminina implica sacrifício e, por conseguinte, uma mulher deveria aceitar dor e desconforto para ficar mais bonita. Assim, as tranças apertadas, apesar de machucarem, são consequência "natural” da busca pela beleza, na mentalidade de Aisha. Por fim, o comportamento rude da cabeleireira senegalesa tem fundamento no próprio enredo: na sequência dos fatos, Aisha está "bufando", cada vez mais irritada por não conseguir impor a Ifemelu sua noção de beleza, já que a cliente recusa a coloração e o alisamento por ela sugeridos, como se estivesse perdendo poder sobre a cliente que manifesta opinião própria.

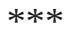

As três etapas aqui abordadas, pelas quais Ifemelu passa, qual sejam, tingimento, alisamento e a feitura das tranças de seu cabelo fazem parte daquilo que Adichie chama de "subcultura" do salão de beleza, que vai muito além do cabelo em si. Para a autora, o ambiente do salão, assim como a tratamento ao cabelo, dizem muito a respeito do que é ser imigrante, ser africana fora da África. O salão, que exerce 


\section{A literatura movente de Chimamanda Adichie}

fascinação sobre Adichie, é definido por ela como um lugar de “tristeza bonita”, em que as mulheres estão construindo vidas novas e assumindo diferentes versões de si mesmas. Em Americanah, Ifemelu é uma personagem que rejeita o "tingimento como fingimento", o "alisamento como submissão” e a "trança afro apertada como opressão”. Pode-se dizer que a protagonista representa a mulher africana em um grau avançado de emancipação, uma ativista que compreende a coloração artificial capilar como sinal de fingimento identitário da mulher negra, o alisamento como subordinação a um padrão de beleza da mulher branca e as tranças apertadas e doloridas como um sacrifício desnecessário em nome da ideia de beleza feminina.

No entanto, a narrativa não é constante na representação de uma Ifemelu sempre forte e decidida, consciente de si mesma, embora essa seja sua imagem predominante. Basta recordar seu desejo, expresso bem na abertura do romance, de querer fingir ser outra pessoa, ser alguém aceito, alguém enfeitado de certeza. De fato, Americanah se constrói no processo que a levou a ser quem ela é, por meio do flashback e das memórias, muitas delas relacionadas ao cabelo afro feminino, como veremos nas seções a seguir.

\subsubsection{O cabelo da mulher negra}

\subsubsection{Na Nigéria}

A razão pela qual Ifemelu vai trançar o cabelo no Mariama African Hair Braiding, relatada no primeiro capítulo do romance, é seu retorno à Nigéria. Essa atitude sugere uma retomada de sua africanidade por meio da reconstrução de um elemento identitário típico. Porém, em meio às digressões da narradora, o leitor aprende que Ifemelu nem sempre quis o cabelo natural. Pelo contrário, precisou fazer alisamento durante muito tempo e precisou passar por uma série de experiências para mudar de ideia, um processo que envolveu a si mesma, e outras mulheres como a amiga Ginika, sua tia Uju e sua mãe.

Ifemelu havia crescido à "sombra do cabelo de sua mãe”, afirma a narradora. Era um cabelo "preto”, tratado no salão, que pendia cheio ao redor de seus ombros 
como se fosse uma festa, orgulho do marido, que o denominava "coroa da glória". Era um cabelo volumoso, que absorvia duas embalagens de alisante a cada tratamento. Um dia, porém, sua mãe chega em casa aflita, com “olhos desfocados”, ansiosa pela tesoura. A menina traz a tesoura para a mãe, que começa a cortar os cabelos, juntando os tufos com todos os objetos católicos que recolhe pela casa, queimando-os no quintal: sua mãe havia se convertido a uma igreja protestante chamada Revival Saints: "Naquela tarde, Ifemelu testemunhou a essência de sua mãe levantando voo. [...] O deus dela havia mudado. Ele havia se tornado meticuloso. Cabelo alisado o ofendia. Dançar o ofendia” (ADICHIE, 2013, p. 42, tradução minha). ${ }^{34}$ Esse fragmento retoma o tema da influência das religiões cristãs na sociedade nigeriana, mas desta vez não como a herança do colonizador do século XIX, já mencionada, mas como uma nova manifestação, preocupante aos olhos de Adichie: o neopentecostalismo do século XXI.

A conversão da mãe do catolicismo para uma religião neopentecostal envolve uma série de restrições relacionadas ao comportamento e à liberdade, dentre as quais o controle do corpo e da aparência feminina, nessa passagem ilustrado pelo cabelo. A conversão foi, na perspectiva de Ifemelu, uma perda de essência, um processo gerador de confusão interna e de ansiedade. Curiosamente, após certo tempo, a mãe anuncia ter visto um anjo, que diz para ela abandonar a igreja Revival Saints e ir para Spring Miracles. Na nova igreja, não há restrições ao cabelo e sua mãe então o deixa crescer novamente. O capítulo segue com a mãe trocando de religião várias vezes, em busca de promessas de salvação e de prosperidade, sendo manipulada em situações que variam entre o cômico e o trágico.

Como uma espécie de trauma de infância, a lembrança do cabelo da mãe de Ifemelu também ajuda a interpretar os problemas que a protagonista enfrenta na fase adulta em relação ao próprio cabelo. Obviamente, a menina, então com dez anos, não sabe avaliar como e por que as restrições e regras religiosas recaem sobre a mulher, determinando até o cabelo feminino, mas a lembrança fica internalizada, sugerindo

34 "That afternoon Ifemelu watched her mother's essence take flight. [...]Her god had changed. He became exacting. Relaxed hair offended Him. Dancing offended Him.” 


\section{A literatura movente de Chimamanda Adichie}

uma questão mal resolvida em torno do cabelo da mulher negra, que mais tarde será revisto em reflexão íntima que Ifemelu faz a respeito de seu próprio cabelo.

Outra lembrança de Ifemelu se refere à experiência de acompanhar sua tia Uju ao caríssimo salão de beleza que frequentava em Lagos, maior cidade da Nigéria. Uju, apesar de ser médica, era sustentada por seu amante, um general rico e poderoso, com quem tinha um filho. Ifemelu era próxima a Uju, a quem admirava como um modelo a ser seguido. Um dia, em visita ao salão de beleza, Ifemelu se espanta com o preço do retoque de alisamento, além do comportamento das cabeleireiras, que escolhiam bajular as clientes mais ou menos dependendo da roupa, do sapato e da bolsa: “Ifemelu assistia, fascinada. Era ali, em um salão em Lagos, que os diferentes ranques da imponência feminina eram melhor compreendidos” (ADICHIE, 2013, p. 77, tradução minha). ${ }^{35}$ Tia Uju sai de lá com apliques capilares que caem sobre seus ombros: Chinese weave-on, a última moda, brilhantes e lisos, os mais lisos existentes. A farra dos salões de beleza sofisticados, porém, termina para Uju quando o general morre de repente. Sem direitos e ameaçada pela família do amante, Uju imigra para os Estados Unidos para poder criar o filho.

\subsubsection{Nos Estados Unidos}

Tia Uju tem uma vida dura em solo estadunidense: trabalha em três empregos para pagar as contas e sustentar o filho, ao mesmo tempo em que se submete a estudos intermináveis e testes dificílimos para obter a permissão para trabalhar como médica naquele país. No dia em que finalmente recebe a licença, Ifemelu está com ela na cozinha. Com olhos marejados, Uju fica em silêncio por uns momentos e diz: “Tenho que tirar minhas tranças para as entrevistas e alisar meu cabelo. [...] Se você tem o cabelo trançado, eles pensam que você não é profissional” (ADICHIE, 2013, p. 120, tradução minha). ${ }^{36}$

\footnotetext{
35 "Ifemelu watched, fascinated. It was here, at a Lagos salon, that the different ranks of imperial femaleness were best understood."

36 "I have to take my braids out for my interviews and relax my hair. [...] If you have braids, they think you are unprofessional."
} 
Ifemelu sorri, achando curioso o fato de que não haveria médicas com cabelos trançados nos Estados Unidos. A tia explica que foi o que disseram a ela e que agora elas estavam em um país que não era o delas e que precisam fazer o que é necessário para ter sucesso. Esse fragmento de Americanah estimula o questionamento: o que vem a ser “cabelo profissional”? Na sociedade estadunidense, a aparência profissional feminina, requerida em seleções de empregos, significa ter cabelos lisos ou alisados, o que força as mulheres negras a se submeterem aos procedimentos de alisamento químico. Diante das explicações da tia, Ifemelu a olha com atenção: era como se tia Uju "tivesse deliberadamente deixado algo de si mesma para trás, algo essencial, em um lugar distante e esquecido” (ADICHIE, 2013, p. 120, tradução minha). ${ }^{37}$ Essa passagem sugere o dilema da assimilação do imigrante, que é se submeter ao que for necessário para obter uma colocação no mercado de trabalho, lançando-se para fora de suas bases identitárias para garantir empregabilidade, uma necessidade que força mulheres imigrantes negras como Uju e Ifemelu a “adequarem” a aparência física.

Ifemelu, porém, é recém-chegada aos EUA e vai aprender por si mesma o que é necessário para se colocar no mercado de trabalho, ao mesmo tempo em que estuda. Ela deseja sair do apartamento da tia, ter seu próprio espaço e ser independente. Para isso busca ajuda em Ginika, amiga nigeriana dos tempos de colégio, que havia imigrado antes. Ginika está muito mais magra, com um cabelo ultra liso “que ela ficava jogando para atrás das orelhas, mechas loiras brilhantes à luz do sol” (ADICHIE, 2013, p. 124, tradução minha). ${ }^{38}$ Aos olhos de Ifemelu, Ginika está americanizada, fala de assuntos desconhecidos, com sotaque americano. Ginika também está decidida a inserir Ifemelu na “América real”, o que significa comprar vestidos sem curvas, que Ifemelu considera deselegantes, dividir um apartamento com outras estudantes e arranjar uma identidade falsa para poder trabalhar.

\footnotetext{
37 “...had deliberately left behind something of herself, something essential, in a distant and forgotten place."

38 "...that she kept tucking behind her ears, blond streaks shiny in the sunlight."
} 


\section{A literatura movente de Chimamanda Adichie}

Ifemelu se inscreve em diversos processos seletivos para emprego, mas nunca é chamada. Seus recursos acabam, o aluguel vence e a situação fica insustentável, até que, em um momento de desespero, Ifemelu aceita um bizarro emprego para “aquecer” um homem com seu próprio corpo. A remuneração serve para pagar o aluguel atrasado, mas lança Ifemelu em uma depressão: embora não tenha ocorrido uma relação sexual, ela se sente prostituída. Estar excluída do mercado de trabalho é para Ifemelu o mesmo que ser invisível nos Estados Unidos, uma condição que a marca profundamente. Em alguns meses, ela se torna babá e consegue pagar as próprias contas. Alguns anos se passam, Ifemelu avança nos estudos na universidade e passa a desejar um novo trabalho, dentro da área profissional que escolheu. Seu namorado, Curt, faz uns contatos e consegue uma entrevista de emprego para ela. Ansiosa para conseguir a vaga, Ifemelu conversa com Ruth, a conselheira profissional da universidade, cuja dica única é: "Solte as tranças e alise seu cabelo. Ninguém comenta esse tipo de coisa, mas faz diferença. Queremos que você consiga aquele emprego” (ADICHIE, 2013, p. 204, tradução minha). ${ }^{39}$

Ifemelu segue o conselho e alisa o cabelo. A princípio, ela não se reconhece no espelho. O namorado também fica surpreso. Ela então mostra a queloide atrás da orelha, marca de queimadura antiga, de outros alisamentos, o que deixa Curt horrorizado. Ele quer saber por que ela precisa alisar o cabelo, que ele considera muito bonito trançado ou simplesmente solto. Ifemelu explica: "Preciso parecer profissional para esta entrevista, e profissional significa que liso é melhor, mas se vai ser cacheado, então tem que ser cacheado no estilo branco, de cachos soltos, ou, na pior das hipóteses, cachos em espiral, mas nunca crespo” (ADICHIE, 2013, p. 206, tradução minha). ${ }^{40}$

A descrição do alisamento químico também choca o leitor que não está familiarizado com a agressividade do processo. À noite, Ifemelu mal consegue deitar a cabeça no travesseiro. Dois dias depois há crostas no couro cabeludo; no terceiro

39 "Lose the braids and straighten your hair. Nobody says this kind of stuff but it matters. We want you to get that job."

40 "I need to look professional for this interview, and professional means straight is best but if it's going to be curly then it has to be the white kind of curly, loose curls or, at worst, spiral curls but never kinky." 
dia, que as feridas soltam pus. Assustado, Curt quer levá-la ao médico, mas ela sorri, explicando que as feridas se curam. No dia seguinte, a entrevistadora anuncia que ela será uma aquisição maravilhosa para a empresa e Ifemelu consegue o emprego, mas deixa o local pensando "se a mulher teria tido a mesma opinião se ela tivesse entrado naquele escritório com sua auréola de cabelo espesso, enroscado, feito por Deus: o Afro” (ADICHIE, 2013, p. 207, tradução minha). ${ }^{41}$

Ifemelu então se recorda de ter achado graça na atitude de sua tia Uju, que anos antes havia alisado os cabelos para ir as entrevistas de emprego. Ifemelu repete a história da tia porque precisa se submeter a um padrão para empregabilidade. Para a mulher negra imigrante, no contexto estadunidense, isso significa ter um "cabelo profissional”, o que torna a questão em torno do cabelo afro ainda mais séria: uma mulher africana ou afro-americana não pode simplesmente optar pelo estilo afro quando necessita de um emprego, mas deve se adequar ao que é considerado profissional, visto que está sujeita ao julgamento de quem detém o poder de contratar ou não.

\subsubsection{Queda de cabelo, ascensão feminina}

A narrativa avança no tempo. Depois de alguns anos, o cabelo de Ifemelu começa a cair, devido ao constante uso de produtos químicos necessários ao alisamento. A amiga Wambui começa a convencê-la a deixar o cabelo natural:

Alisar seu cabelo é como estar na prisão. Você fica enjaulada. Seu cabelo manda em você. Você não saiu para correr com o Curt hoje porque não queria suar e estragar esta lisura. Naquela foto que você me mandou, você estava com o cabelo coberto no barco. Está sempre lutando para fazer seu cabelo ser aquilo que ele não foi feito para ser.

41 “...if the woman would have felt the same way had she walked into that office wearing her thick, kinky, God-given halo of hair, the Afro." 


\section{A literatura movente de Chimamanda Adichie}

Se deixar o cabelo natural e cuidar bem dele, não vai cair como está caindo agora. (ADICHIE, 2013, p. 210, tradução minha). ${ }^{42}$

Ifemelu então corta o cabelo bastante curto e odeia o resultado, sentindo-se feia como um inseto e parecida com um garoto. Curt tenta ajudar, mas ela sequer vai trabalhar. No dia seguinte, Wambui indica o site HappilyKinkyNappy.com, algo como EnroscadoCrespoFeliz.com, uma comunidade virtual de mulheres negras dedicada à aceitação e cuidado dos cabelos afro naturais. No princípio, Ifemelu acha a iniciativa infantil, mas aos poucos vai examinando as fotos, com os mais diversos estilos de cabelo, e lendo os comentários das participantes, elogiando umas às outras. Começa a aprender a respeito de produtos próprios para cabelos afro, nunca mencionados em revistas de beleza, dando início a um processo de aceitação do próprio cabelo:

Em um dia qualquer no início da primavera, um dia sem nenhuma luz especial, nada de significativo aconteceu [...] ela se olhou no espelho, afundou os dedos em seu cabelo, denso, macio e glorioso, e não conseguia mais imaginá-lo de nenhuma outra maneira. Assim, de maneira simples, ela se apaixonou por seu cabelo. (ADICHIE, 2013, p. 215, tradução minha). ${ }^{43}$

O romance, nesse capítulo, oferece uma espécie de clímax no que se refere ao tema cabelo, remetendo-nos a uma declaração de Adichie em entrevista a John Mullan, na página eletrônica do jornal The Guardian: "Gosto de fatias de felici-

\footnotetext{
42 “Relaxing your hair is like being in prison. You're caged in. Your hair rules you. You didn't go running with Curt today because you don't want to sweat out this straightness. That picture you sent me, you had your hair covered on the boat. You're always battling to make your hair do what it wasn't meant to do. If you go natural and take good care of your hair, it won't fall off like it's doing now."

43 "On an unremarkable day in early spring - the day was not bronzed with special light, nothing of any significance happened [...] she looked in the mirror, sank her fingers into her hair, dense and spongy and glorious, and could not imagine it any other way. That simply, she fell in love with her hair.”
} 
dade, fatias de redenção” (ADICHIE, 2014, tradução minha),${ }^{44}$ diz a autora, ao comentar Americanah. A pequena redenção, neste caso, é o momento íntimo de descoberta pessoal da protagonista: apaixonar-se pelo próprio cabelo é dar um passo fundamental de autoestima e de emancipação para a mulher negra. O fato constitui uma pequena revolução individual, de certa forma desejada pelo leitor que, a essa altura, torce para que Ifemelu se liberte e pare de alisar o cabelo. Poderia esse fato constituir um exemplo daquilo que denomino descolonização cultural? A princípio sim, pois a personagem se reposiciona no mundo de maneira a se sentir melhor, eliminando um aspecto da opressão que, conforme visto, tem origem no emaranhado de ideias e valores da colonização, figurando disfarçadamente na modernidade. Entretanto, há de se considerar as novas circunstâncias de Ifemelu: esse momento de delicada redenção, por meio da aceitação do cabelo afro, ocorre em paralelo com sua independência econômico-financeira, que chega, a princípio, porque ela conquista uma posição estável no trabalho e, um pouco mais tarde, por não mais depender do emprego em que está: ela passa a ser bem remunerada como blogueira, devido ao sucesso de seu blog sobre raça, que possui patrocinadores e lhe rende convites para palestras. Dessa forma, a narrativa não cronológica de Adichie nos permite "sonhar" por um instante ao oferecer apenas "uma fatia" de felicidade e de redenção, em linguagem quase poética: Ifemelu apaixonando-se pelo próprio cabelo. Alguns capítulos mais tarde, no entanto, a narradora expõe detalhes sobre como os leitores do blog de Ifemelu vão aumentando, como apoiadores passam a enviar contribuições financeiras à autora, como empresas de maior porte passam a anunciar nas páginas do blog e como os convites para palestras remuneradas se multiplicam. Assim, é possível concluir que apaixonar-se pelo cabelo natural e passar a mantê-lo sem alisamentos não é uma decisão romântica, fruto de uma simples escolha, mas é concretamente ligada à autonomia que Ifemelu adquire em relação ao mercado de trabalho tradicional.

44 “I like slices of happiness, slices of redemption.” Disponível em: <https://www.theguardian.com/ books/ audio/2014/aug/01/chimamanda-ngozi-adichie-americanah-podcast> Acesso em: 7 Out. 2016. 


\section{Alisar ou não alisar? Eis a questão!}

Até certo ponto na narrativa, a relação de Ifemelu com seu cabelo tende a ser interpretada predominantemente como parte da esfera privada, uma escolha do indivíduo, até que o dilema da empregabilidade da mulher negra no mercado de trabalho estadunidense entra em cena para dizer ao leitor que o cabelo afro é também um problema da esfera pública. Creio que seja proposital que a trajetória de Ifemelu seja narrada de forma a balancear o privado e o público, fazendo o leitor refletir sobre questionamentos mais abrangentes: o que é predominante na vida das pessoas - o livre-arbítrio ou o determinismo? A protagonista é livre para fazer escolhas sobre sua vida ou é levada por circunstâncias externas, além de seu controle?

Americanah traz a controvérsia para a esfera pública de maneira incisiva no capítulo 31, em uma publicação no blog de Ifemelu. É 2008, ano em que Barack Obama está em campanha para a presidência dos Estados Unidos. Intitulado "Um brado de Michelle Obama + o cabelo como metáfora para raça” (ADICHIE, 2013, p. 299, tradução minha), ${ }^{45}$ o texto que Ifemelu publica nesse dia é motivado por uma observação: Michelle Obama parece usar um aplique, que deve esquentar e incomodar, além de danificar seu cabelo natural. A blogueira, então, inicia uma discussão sobre como programas de TV apresentam o "antes” e o “depois” de mulheres negras: o antes, considerado feio, com cabelos crespos ou encaracolados, e o depois trazendo cabelos alisados como sinônimo de beleza. Algumas mulheres negras, americanas ou não, avalia Ifemelu, preferem sair nuas à rua a aparecer em público com seu cabelo natural: aprenderam que não é profissional e nem sofisticado, não é normal. Nos Estados Unidos, a sociedade vê a mulher negra que vai a público com o cabelo natural como alguém que fez "algo" no cabelo, fazendo parte de um ato político, uma poeta, artista ou cantora. Ifemelu, entretanto, deseja

\footnotetext{
45 "A Michelle Obama Shout-Out Plus Hair as Race Metaphor"
} 
inverter essa lógica deturpada, explicando que as mulheres com o cabelo afro, pelo contrário, não fizeram tratamento especial, podendo significar a simples atitude de uma mulher normal que não deseja fazer uso da pesada química dos alisantes, que são cancerígenos. A blogueira, então, pede ao leitor:

Imagine se Michelle Obama se cansasse de todo o calor [provocado pelo aplique] e decidisse usar o cabelo natural e aparecesse na TV com muito cabelo tipo algodão ou cachos em espirais miúdas. Ela arrasaria, mas o pobre Obama certamente perderia o voto independente e até mesmo os votos dos Democratas indecisos. (ADICHIE, 2013, p. 299, tradução minha). ${ }^{46}$

Aqui o caráter político do cabelo é trazido para o jogo político em si. Nos Estados Unidos, uma mulher negra de cabelo afro, trançado ou de dreads é vista como radical, extremista ou exasperada ou, na melhor das hipóteses, artista. Para não transmitir essa imagem, Michelle Obama alisa o cabelo e, como Adichie viria a declarar, em entrevistas, Barack Obama não teria vencido as eleições se Michelle não o tivesse feito. ${ }^{47}$ Isso equivale a dizer que alisar se torna, nesse contexto, um ato político tão contundente que contribui para levar o primeiro homem negro da história à presidência do país considerado o mais poderoso do planeta. Essa ponderação também problematiza a resposta para a pergunta: alisar ou não alisar? Afinal, Americanah aponta situações divergentes em que o procedimento pode pro-

${ }^{46}$ Imagine if Michelle Obama got tired of all the heat and decided to go natural and appeared on TV with lots of woolly hair, or tight spirally curls [...] She would totally rock but poor Obama would certainly lose the independent vote, even the undecided Democrat vote."

${ }^{47}$ A importância da relação entre o cabelo de Michelle Obama e o poder político de seu marido, tema dos blogs fictícios de Ifemelu, pôde ser confirmada na vida real, por uma foto divulgada em março de 2017, que viralizou na internet, na qual Michelle Obama aparece com o cabelo natural. As reações foram aos milhares. O jornal inglês Independent noticiou: "Michelle Obama é fotografada com cabelo natural depois de mantê-lo alisado durante oito anos na Casa Branca”. Longe das implicações do cargo, a ex-primeira dama dos Estados Unidos se viu em situações menos protocolares e menos coercitivas, permitindo-se, finalmente, interromper o constante alisamento do próprio cabelo. 


\section{A literatura movente de Chimamanda Adichie}

porcionar empoderamento em uma situação e tirá-lo em outra. Assim, o romance, talvez despretensiosamente, leva-nos a enxergar que o cabelo da mulher negra é algo que não pode ser julgado em termos de padrões ou categorias fixas, tanto no caso da protagonista Ifemelu quanto no comentário sobre Michelle Obama. Não há, portanto, uma receita única a ser seguida pelas mulheres negras.

A emancipação da mulher negra em Americanah se torna um tema paradoxal, com base na questão sobre alisar ou não alisar o cabelo. Esse paradoxo foi um dos fatores que me levaram a pensar a noção de descolonização de maneira mais cuidadosa. Primeiramente, tive que considerar a descolonização além dos seus significados mais usuais, que se referem a ela como o processo histórico, político e social em que um país que era uma colônia torna-se independente. Essa é uma perspectiva que inspirou obras de prestígio, como o já citado trabalho de Albert Memmi (2006). Porém, as obras teóricas a que recorri para explorar o tema da descolonização não pareciam estar interessadas em incluir certas práticas culturais nas discussões que traziam sobre o processo. Devido a isso, proponho a adição da palavra “cultural” para repensar descolonização a partir da expressão “descolonização cultural”. Meu argumento é o de criar, por meio da ampliação do sentido de descolonização, a possibilidade de abranger temas como cabelo, maquiagem, vestuário, comida ou qualquer outra forma de prática cultural que não tenha sido incluída nos estudos da descolonização até agora. A abordagem de Adichie sobre a controvérsia do cabelo e, por conseguinte, para a emancipação das mulheres pós-coloniais negras no romance Americanah me ensinou que todas essas práticas e valores culturais merecem ser discutidos.

Além do próprio Americanah, o conceito de descolonização cultural que proponho tem relação com o que Michel Foucault (2015) chama de microfísica de poder. Foucault enfatiza que o poder está em toda parte, movendo-se constantemente, e sua análise deve ser feita a partir de seus mecanismos infinitesimais e da forma como 
eles são manipulados. Assim, examinar os procedimentos de poder nos detalhes da vida, em fatores considerados pequenos e triviais, e tentar compreender como esse poder se move, se expande e muda, pode levar a dois resultados: o de que tais detalhes não são tão pequenos e triviais como se pensava e, como pondera Foucault, pode levar à compreensão do poder em níveis mais altos ou «poderes mais gerais ou lucros econômicos”, mesmo a dominação global (FOUCAULT, 2015, p. 284).

Esse foi o caso da análise que fiz sobre alisar ou não alisar o cabelo afro de uma mulher negra. Trata-se apenas de um exemplo sobre como age esse mecanismo do poder foucaultiano, um "mecanismo infinitesimal” nas sociedades que consideram os assuntos femininos como triviais. Um grupo de homens que teorizam "grandes questões” como a queda de sistemas coloniais ou o surgimento de novos Estados-nações certamente não pensaria em práticas culturais do universo feminino como parte da descolonização.

Dito isso, faz-se mister retomar a definição inicial que propus para a descolonização cultural, no tocante ao reposicionamento de indivíduos e sociedades pós-coloniais, a fim de apontar alguns aspectos complementares. Ficou claro, por exemplo, que a descolonização cultural é uma questão de gênero também, não apenas porque uma autora mulher resolveu escrever um romance sobre o cabelo da mulher pós-colonial negra, africana e imigrante, mas pelo simples fato de que ignorar qualquer tema relativo a elas é no mínimo irresponsável em um planeta com 3,75 bilhões de mulheres, e, por certo, levará qualquer análise a distorções e incongruências. Essa abrangência vem junto com a controvérsia das especificidades, isto é, a emancipação discutido a partir de um tema como o cabelo também mostra como descolonização cultural varia de um indivíduo para outro, de um grupo para outro, podendo apresentar ritmos específicos em cada sociedade.

Tal variação que caracteriza o panorama da descolonização cultural também tem referência na diversidade de tempos e de espaços. Daí originou-se minha escolha por pensá-la a partir de um romance contemporâneo, porém “impregnado de passado" como Americanah, que focaliza espaços distantes e distintos do meu 


\section{A literatura movente de Chimamanda Adichie}

próprio país, que é meu lócus de enunciação. Também o fato de que Americanah, exemplo maior do caráter movente da literatura de Adichie, é uma representação de três continentes, possível de ser feita pela mobilidade de suas personagens, às voltas com conflitos pessoais muito além do tempo presente.

Essa tensão entre o individual e o coletivo, ilustrada no romance, é frequentemente mal compreendida por ativistas nos mais variados movimentos pós-coloniais, sobretudo nos períodos pós-independência, quando protagonistas surgem ansiosos por difundir o conhecimento adquirido, por conscientizar as grandes massas sobre as correntes que as aprisionam. Em países pós-coloniais, líderes políticos à frente de movimentos sociais frustram-se ao perceberem que muitos de seus compatriotas não aceitam seu discurso, como se não desejassem se emancipar, desconfiando de qualquer mudança proposta. O que ocorre é que há tentativas de forçar projetos políticos ligados a uma visão de descolonização cultural unilateral, o que se revela inútil. Afinal, além de nem todos estarem prontos para mudanças, a conquista de autonomia, o reposicionamento que beneficia o indivíduo e as sociedades, é culturalmente muito específico. Além disso, toda tentativa de impor ideias ou práticas a outrem, como as que ocorreram nos tempos pós-independência, significa recair no erro primário da repetição das estratégias de opressão e de dominação do colonizador.

Outra consideração a ser feita está no fato de a descolonização cultural no século XXI ser diferente de buscar recuperar a cultura pré-colonial, como apregoam alguns intelectuais do pós-colonialismo. ${ }^{48}$ Esclarecendo essa linha de raciocínio por meio da análise aqui feita, uma mulher negra do século XXI que decide parar de alisar o cabelo e mantê-lo natural não o fará no mesmo estilo e nas mesmas condições de suas antepassadas pré-coloniais do século XVII. Meu argumento é o de que a descolonização cultural trata, na verdade, de como o sujeito pós-colonial

\footnotetext{
48 Jeyifo (1991) cita Ngugi Wa Thiong’o, Naguib Mahfouz e Octavio Paz como exemplos de intelectuais que se empenharam no estabelecimento de uma "voz da nação” ou da comunidade regional a que estavam vinculados, baseados na ideia de retorno às raízes pré-coloniais.
} 
pode construir um novo senso de sua própria humanidade, sem fórmulas específicas, a partir da revisão de suas práticas culturais, que são frutos de muitas influências, dentre elas o colonialismo, e que são predicadas da pós-colonialidade como conjuntura em que a hibridização e a traduzibilidade caracterizam todas as culturas.

Vale lembrar ainda que hibridização e traduzibilidade, temas que tratei a partir de Young (2003) e Rushdie (1991), ensejam perdas, mas também ganhos. Dessa forma, pensar que se pode reconstituir o passado pré-colonial é algo no mínimo utópico, certamente baseado em uma noção romântica de que havia culturas puras ou de que não havia problemas antes da chegada do colonizador. Esse fato da passagem dos colonizadores pela África e pelos outros continentes, somado às marcas que deixaram, constitui-se em um dado irrefutável da condição pós-colonial com o qual se deve lidar a partir de estratégias múltiplas e específicas. Também irrefutável é o fato de uma ampla mobilidade humana ter se iniciado após a independência das colônias, tema que tratarei por meio da Teoria da Diáspora no próximo capítulo. 